\title{
AS DECISÕES JUDICAIS NO CONTROLE DE CONSTITUCIONALIDADE E A SUA EFICÁCIA VINCULANTE NO ESTADO DEMOCRÁTICO DE DIREITO
}

\section{THE JUDICIAL DECISIONS ON THE JUDICIAL REVIEW AND THEIR BINDING EFFECT ON THE DEMOCRATIC STATE OF LAW}

\author{
GUILHERME CÉSAR PINHEIRO \\ Mestre em Direito Professual pela Pontifícia Universidade Católica de Minas Gerais. \\ Professor da Universidade Estadual de Minas Gerais \\ guilhermepinheiro.adv@hotmail.com
}

RICARDO NOBREGA Bacharel em Direito pela Universidade de Brasília (2000), mestre em Sociologia pelo Instituto Universitário de Pesquisas do Rio de Janeiro / IUPERJ (2005. Doutor em Sociologia pelo IESP-UERJ (2014). Pesquisador do NETSAL / IESP-UERJ guilhermepinheiro.adv@hotmail.com

\section{RESUMO}

Este artigo tem como objetivo estudar de forma resumida os contornos e conteúdos das decisões judiciais proferidas no controle de constitucionalidade das leis: interpretação conforme à Constituição, Declaração de nulidade parcial sem redução de texto, aditivas e substitutivas. Assim, o que se busca é inserir o interlocutor em um importante e atual debate do direito constitucional, sobretudo da hermenêutica constitucional do pós giro linguístico. Com isso, será possível acentuar os limites dos conteúdos de tais decisões, sob o ponto de vista da tênue diferença entre as funções Jurisdicional e Legislativa no marco do Estado Democrático de Direito. Ao final, algumas considerações de natureza crítica e reflexiva a respeito da pretensão de conferir efeito erga omnes e eficácia vinculante a tais decisões quando proferida pelo Supremo Tribunal Federal mostram-se necessária. Isso se destina a instaurar ponto de reflexão na comunidade jurídica em geral. Particularmente, pela circunstância de que o propósito da eficácia vinculante é eleger o Supremo Tribunal Federal como intérprete oficial da Constituição, o que é destoante dos preceitos democráticos da constitucionalidade brasileira, além de ser impossível engessar a interpretação por intermédio do resultado de uma decisão vinculante.

Palavras-chave: Jurisdição Constitucional; Legitimidade democrática; Vinculação decisória; Estado Democrático de Direito

\begin{abstract}
This article aims to study briefly the contours and content of judgments made in the control of constitutionality of laws: interpretation according to the Constitution, Declaration of invalidity without partial reduction of text, additive and substitutive. So, what is sought is to enter the party on important and current debate of constitutional law, especially the constitutional hermeneutics post linguistic turn. With it, you can emphasize the limits of such decisions contents, from the point of view of the slight difference between the Constitutional and Legislative work within the framework of the democratic rule of law. Finally, some considerations of critical and reflective nature concerning the claim to confer erga omnes effect and binding effect to such decisions when rendered by the Supreme Court show up required. This is to bring reflection point in the legal community in general. In particular, by the fact that the purpose of binding effect is to elect the Supreme Court as the official interpreter of the Constitution, which is jarring democratic precepts of the Brazilian constitutionality, besides being impossible stifle interpretation through the result of a binding decision.
\end{abstract}

Keywords: Constitutional Jurisdiction; Democratic legitimacy; Binding decisions; Democratic State of Law. 


\section{SUMÁRIO}

INTRODUÇÃO; 1 CONSIDERAÇÕES INTRODUTÓRIAS SOBRE A JURISDIÇÃO CONSTITUCIONAL E AS DECISÕES INTERMEDITÁRIAS; 2 DAS DECISÕES INTERPRETATIVAS (INTERPRETAÇÃO CONFORME À CONSTITUIÇÃO E DECLARAÇÃO DE NULIDADE PARCIAL SEM REDUÇÃO DE TEXTO); 3 SOBRE AS DECISÇOES MODIFICATIVAS (ADITIVAS E SUBSTITUTIVAS); 4 UMA LEITURA HERMENÊUTICA DA PRETENSÃO DE VINCULAÇÃO DAS DECISÇOES DO CONTROLE DE CONSTITUCIONALIDADE NO ESTADO DEMOCRÁTICO DE DIREITO; CONCLUSÃO; REFERÊNCIAS.

\section{INTRODUÇÃO}

É inegável a importância que o Direito brasileiro tem atribuído à jurisprudência, sobremaneira as decisões proferidas pelo Supremo Tribunal Federal, seja no âmbito do controle concentrado de constitucionalidade, seja no âmbito do controle difuso. E o propósito dessa atribuição significativa de importância a tais decisões é combater a pluralidade de interpretação e, consequentemente, uniformizar a jurisprudência.

Nessa perspectiva, várias medidas no plano técnico (legiferante) foram adotadas. Em plano constitucional, por exemplo, com a emenda à Constituição número 3 do ano de 1993, foi inserido na sistemática brasileira o controle concentrado de constitucionalidade, cujas decisões têm eficácia vinculante e efeitos erga omnes. Igualmente, por meio de emenda à Constituição (número 45 de 2004) foram instituídas as súmulas vinculantes do Supremo Tribunal Federal. No âmbito do Código de Processo Civil, a Lei de número 9.756/98 alterou as redações dos artigos 481 , § único, e 557 , caput e $\S 1^{\circ}$, criando a possibilidade de o relator não conhecer de recursos que impugnem decisões cujo conteúdo estiver conforme a "jurisprudência dominante" ou a enunciado sumular do Tribunal correspondente. Além disso, instituiu a possibilidade de o relator dar provimento, monocraticamente, em caso de o recurso ser compatível com a jurisprudência do Supremo Tribunal Federal ou tribunais superiores.

Há várias outras modificações pertinentes ao tema, mas, considerando os limites deste artigo, não há a necessidade de destacá-las. O que se quer acentuar é que essas e outras modificações legislativas visam à uniformização da jurisprudência, por intermédio de mecanismo de vinculação decisória, o que resolveria o problema da existência de uma pluralidade de decisões judiciais a respeito de um mesmo tema jurídico. É que a ausência de uniformização decisória afetaria a certeza e a segurança jurídica, na medida em que não se tem previsibilidade das decisões judiciais, bem como pela circunstância de situações semelhantes receberem 
ISSN 1981-3694

(DOI): $10.5902 / 1981369419761$

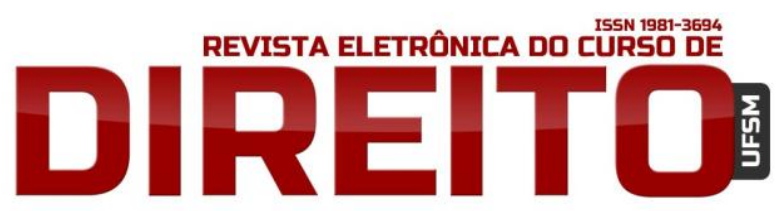

AS DECISÕES JUDICAIS NO CONTROLE DE CONSTITUCIONALIDADE E A SUA EFICÁCIA VINCULANTE NO ESTADO DEMOCRÁTICO DE DIREITO

soluções díspares do Judiciário.

Mas a tentativa de se solucionar o problema da ausência de uniformidade decisória por intermédio de atribuição de eficácia vinculante a decisões proferidas pelo Supremo Tribunal Federal traz algumas questões que reclamam reflexão pela comunidade jurídica. Por exemplo: seria legítimo admitir que o conteúdo de uma decisão do Supremo Tribunal Federal não possa ser “revisitado" e modificado por outro órgão do Judiciário? Aplicar uma decisão vinculante significa aceitar que a jurisdição exerça atividade criativa de direitos? As decisões vinculantes devem ser aplicadas (observadas, seguidas) por argumentos de autoridade ou pelos seus fundamentos teórico-normativos?

Assim, este artigo pretende problematizar algumas questões atinentes à atribuição de eficácia vinculante das decisões do controle judicial de constitucionalidade das leis, sob o enfoque da legitimidade democrática da jurisdição constitucional.

Para tanto, primeiramente, faz-se necessário apresentar algumas noções introdutórias acerca das decisões do controle de constitucionalidade, especialmente de que maneira os mencionados atos judiciais atualmente se inserem na temática da Ciência do Direito.

Em seguinte, analisar-se-ão os conteúdos das decisões do controle judicial de constitucionalidade das leis, procurando compreendê-las do ponto de vista da legitimidade da jurisdição, sempre a partir de análise de casos concretos.

Após, será feita uma proposta de leitura hermenêutica da pretensão de atribuição de vinculação das decisões do controle de constitucionalidade no Estado Democrático de Direito, também a partir de análise de casos concretos.

É a partir disso tudo que se procurará inserir o interlocutor em importante e atual tema do Direito Constitucional, particularmente da Hermenêutica Constitucional do pós giro linguístico.

\section{CONSIDERAÇÕES INTRODUTÓRIAS SOBRE A JURISDIÇÃO CONSTITUCIONAL E AS DECISÕES INTERMEDITÁRIAS}

É importante ressaltar que essa temática refere-se ao embate teórico entre as noções de que a jurisdição constitucional desempenharia a função de “legislador negativo" ou se seria possível (e legítimo) compreendê-la numa perspectiva intermediária entre as funções jurisdicional e legislativa, especialmente no que se refere ao controle de atos do Legislativo. 
ISSN 1981-3694

(DOI): $10.5902 / 1981369419761$

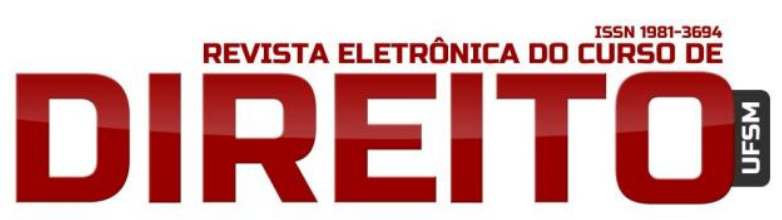

AS DECISÕES JUDICAIS NO CONTROLE DE CONSTITUCIONALIDADE E A SUA EFICÁCIA VINCULANTE NO ESTADO DEMOCRÁTICO DE DIREITO

GUILHERME CÉSAR PINHEIRO RICARDO NOBREGA

É que a noção de "legislador negativo" é ligada ao positivismo exegético na medida em que só caberia à jurisdição constitucional a tarefa de dizer se determinada norma é ou não constitucional e, nesse último caso, declarar a nulidade do texto legislativo, extirpando-o do ordenamento jurídico. Ou seja, era oito ou oitenta. Essa acepção também desconsiderava a distinção entre texto e norma ${ }^{1}$. Acreditava-se que a jurisdição constitucional se concretizaria na atividade de comparação abstrata entre os textos da legislação ordinária e o da Constituição, de forma apartada de um problema concreto (caso concreto, demanda judicial).

Nessa perspectiva, aproveitando-se dos ganhos da hermenêutica constitucional, principalmente a distinção entre texto e norma e a noção de aplicação de uma norma não pode ocorrer de forma dissociada da concretude. Isto é, deve-se repelir a ideia de que a jurisdição constitucional é vinculada à noção de processo objetivo e sem partes.

Acrescenta-se a esse contexto, a circunstância de que desde o fim da Segunda Guerra Mundial o Judiciário alcançou um lugar de destaque nas democracias e o processo jurisdicional passou a ser compreendido como "um espaço contramajoritário de obtenção de direitos fundamentais" (THEODORO JÚNIOR; NUNES; BAHIA, 2010, p. 12 e 15). 0 que não significa conceber o Judiciário como superego de uma "sociedade órfã" que o reverenciaria de forma religiosa ${ }^{2}$ (MAUS, 2000, p. 185). A jurisdição deve sim servir para realizar controle dos atos do Legislativo e do Executivo, mas ao fazê-lo é indispensável que seus atos sejam apoiados em normas, vez que, se assim não for, carecerá de legitimidade.

Por último, existem exigências de quórum qualificadas tanto para o julgamento quanto para a decisão de inconstitucionalidade de ato normativo impugnado. Em termos que controle concentrado, a lei 9.868/99, nos seus artigos 22 e 23, estabelece que o julgamento do pleito de inconstitucionalidade deve ser realizado com a presença de pelos menos 8 ministros do STF. Sendo que declaração de constitucionalidade e inconstitucionalidade precisa de pelos menos 6 votos (maioria absoluta), em qualquer sentido.

\footnotetext{
${ }^{1}$ As normas são o resultado intelectivo da interpretação do texto legislativo, de modo que "a distinção entre norma e texto jurídico resida exatamente no fato de que aquela só existe se for haurida do texto legal pelo intérprete" (CORDEIRO LEAL, 2000, p. 117). Rosemiro Pereira Leal exemplifica muito bem a distinção que ora se quer realçar, nos seguintes termos "[...] norma não é algo escrito, mas uma categoria intelectiva, que inferida do texto legal, indica o padrão de licitude da conduta [...]" (LEAL, 2009, p. 124), ou seja, diz se esta é devida, permitida ou proibida. Logo, levando-se em consideração o texto do artigo 121 do Código Penal brasileiro "Matar alguém. Pena de 06 a 12 anos.", o que daí se infere é que é proibido matar outra pessoa.

${ }^{2}$ Sobre esta proposta de Ingeborg Maus, conferir o interessante texto: (BAHIA, 2005).
} 
ISSN 1981-3694

(DOI): $10.5902 / 1981369419761$

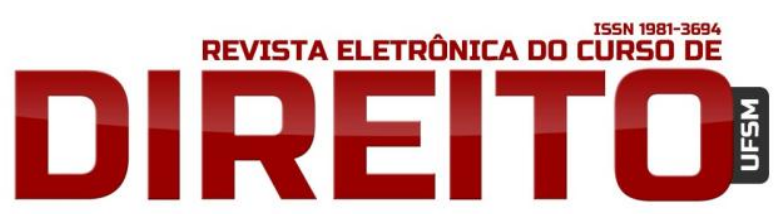

AS DECISÕES JUDICAIS NO CONTROLE DE CONSTITUCIONALIDADE E A SUA EFICÁCIA VINCULANTE NO ESTADO DEMOCRÁTICO DE DIREITO

Sob tais premissas, foi cunhada a expressão "sentenças intermediárias". Cumpre mencionar que essa expressão foi difundida no Brasil pelo constitucionalista José Adércio Leite Sampaio. Mas sua origem data do ano de 1987, no VII congresso de tribunais constitucionais europeus. Com essas decisões têm o sentido de estabelecer a ideia de que no exercício da jurisdição constitucional seria possível buscar soluções intermediárias ao binômio constitucional/inconstitucional.

Isso ocorre por intermédio das chamadas sentenças intermediárias que, ao se atribuir a determinado texto legislativo qual é o sentido adequado à Constituição, acaba por excluir aquelas hipóteses de interpretações inconstitucionais, além de solucionar e as demandas judiciais que reclamam o controle de constitucionalidade das leis.

Mas cabe um reparo terminológico aqui. É mais adequado fazer referência às decisões intermediárias, ao invés de sentenças intermediárias. Isso porque as sentenças são aqueles atos decisórios (que resolvem ou não o mérito da demanda, nos termos dos artigos 267 e 269 do Código de Processo civil) proferidos por juízes de primeira instância (ou juízos monocráticos), não abarcando aqueles atos decisórios proferidos em segunda instância e em colegiado. Com isso, a expressão decisão, por ser mais abrangente, se adéqua melhor ao caso.

Outro esclarecimento que se faz é concernente ao tratamento conjunto das modalidades de controle de constitucionalidade das leis. Apesar de haver diferenças de ordem técnica entre os modelos controle difuso e concentrado, a presente abordagem não se preocupará se são apenas as decisões proferidas no âmbito do controle concentrado e abstrato que possuem eficácia vinculante e efeito erga omnes, segundo a dicção do artigo 28 da Lei 9868/1999. Isso porque para a vertente do Direito como integridade (DWORKIN, 2007) mesmo que a legislação não determine que o conteúdo de uma decisão deva ser observado por outros órgãos do Judiciário ou pelo Executivo, é preciso que o conteúdo desses atos decisórios integrem a discussão processual, não podendo os sujeitos processuais negar-lhe importância. Deve-se ressaltar o fato de que se estará diante de uma decisão judicial que expressa uma interpretação da Constituição, a qual também será objeto de compreensão por todos os possíveis intérpretes. Em outras palavras, o mais importante é que tanto as decisões oriundas do controle de constitucionalidade difuso quanto aquelas do controle concentrado imprescindivelmente serão objetos de interpretação. Com efeito, não se poderá desconsiderar as peculiaridades de caso concreto, ao se proceder à atribuição de sentido aos mencionados atos decisórios. É somente a partir de uma situação fática, reconstruída exaustivamente, mediante a descrição de todas as características relevantes para a sua apreciação, que se poderá chegar à solução adequada, visto 
ISSN 1981-3694

(DOI): $10.5902 / 1981369419761$

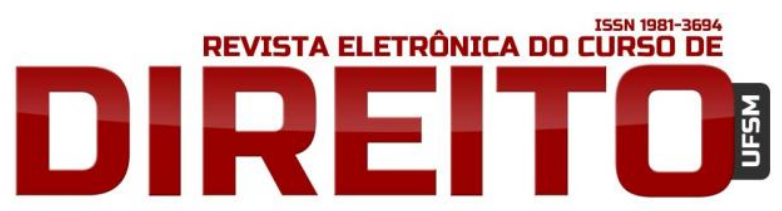

AS DECISÕES JUDICAIS NO CONTROLE DE CONSTITUCIONALIDADE E A SUA EFICÁCIA VINCULANTE NO ESTADO DEMOCRÁTICO DE DIREITO

que não é possível antever todas as hipóteses em que determinada norma colidirá com alguma outra norma constitucional (SILVA FILHO, 2003, p. 175). Logo, a força vinculante das decisões não advém da legislação, antes de seus fundamentados (argumentos) teórico-normativos.

Nesse passo, seguindo-se a proposta de José Alfredo de Oliveira Baracho Júnior, cabe estabelecer um diálogo no entremeio desses dois modelos de controle de constitucionalidade das leis, sem qualquer pretensão de buscar a superação de um modelo pelo outro. Isso porque é possível realizar um diálogo, ainda que tais modelos sejam "antagônicos” (BARACHO JÚNIOR, 2009, p. 166), principalmente pela circunstância de que o que aqui será ressaltado são os conteúdos e os efeitos das decisões que expressem interpretação da Constituição.

De conseguinte, o ponto nevrálgico do controle de constitucionalidade é a sua legitimidade, sendo inadmissível qualquer discricionariedade nas decisões atinentes à fiscalidade democrática das leis. Não é a aposta na sapiência de um conjunto de Ministros de uma Corte Constitucional ou em juízos ordinários que se dará conta das perplexidades inerentes ao constitucionalismo democrático.

Com isso, é possível refletir que não é pela adoção de um ou outro sistema de controle de constitucionalidade que os problemas atinentes à segurança jurídica, à certeza do Direito e à sobrecarga do Judiciário serão resolvidos, sem afetar negativamente os princípios constitucionais e a legitimidade normativa.

\section{DAS DECISÕES INTERPRETATIVAS (INTERPRETAÇÃO CONFORME À CONSTITUIÇÃO E DECLARAÇÃO DE NULIDADE PARCIAL SEM REDUÇÃO DE TEXTO)}

Ao se tratar das decisões do controle judicial de constitucionalidade das leis, por questões didáticas, mostra-se necessário que se reúna tais atos decisórios em grupos, com o fito de facilitar a compreensão de seus conteúdos.

Nesse sentido, adota-se a classificação empreendida por Emílio Peluso Neder Meyer, vez que ela apresenta-se como a mais didática. 0 autor divide as decisões em interpretativas (interpretação conforme, declaração de nulidade parcial sem redução de texto), modificativas (aditivas ou substitutivas) e transitivas ou transacionais (declaração de inconstitucionalidade de 
ISSN 1981-3694

(DOI): $10.5902 / 1981369419761$

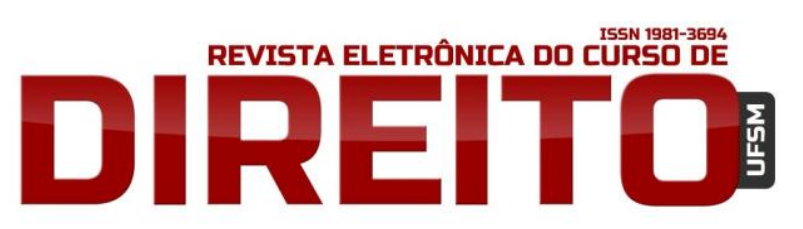

AS DECISÕES JUDICAIS NO CONTROLE DE CONSTITUCIONALIDADE E A SUA EFICÁCIA VINCULANTE NO ESTADO DEMOCRÁTICO DE DIREITO

GUILHERME CÉSAR PINHEIRO RICARDO NOBREGA

caráter restritivo ou limitativo e a declaração de inconstitucionalidade sem pronúncia de nulidade) (MEYER, 2008, p. 40) ${ }^{3}$.

Desde já importa dizer que as decisões transitivas ou transacionais, que são aquelas designadas de "declaração de inconstitucionalidade sem pronúncia de nulidade" e de “declaração de inconstitucionalidade de caráter restritivo ou limitativo"4 não serão analisadas por dois motivos básicos. Primeiro, pelo fato de que, a despeito de reconhecerem expressamente a inconstitucionalidade de determinado texto legiferante, não determinam sua extirpação do ordenamento jurídico. Segundo, porque postergam a anulação de tal texto para

${ }^{3}$ Encontram-se outras classificações interessantes. Por exemplo, José Adércio Leite Sampaio catalogar tais decisões em apenas dois grupos: (1) um das sentenças normativas, sendo aquelas que criam normas gerais; outro das sentenças transitivas ou transacionais, sendo aquelas que anunciam uma transitoriedade ou uma relativa transação com o princípio da supremacia da constitucional em seus conteúdos. São reunidas no grupo das sentenças normativas as decisões de interpretação conforme à Constituição, as aditivas, as aditivas de princípios e as substitutivas No grupo das sentenças transitivas ou transacionais ficam reunidas aquelas decisões de inconstitucionalidade sem efeito ablativo, de inconstitucionalidade com ablação diferida ou datada, as sentenças apelativas ou de declaração da constitucionalidade provisória ou de declaração de "todavia constitucionalidade" e as sentenças de aviso. (SAMPAIO, 2001, p. 163-176). Gilmar Ferreira Mendes divide as decisões em perspectiva comparatista; Num grupo as decisões proferidas no controle abstrato de normas perante a Corte Constitucional Alemã: declaração de nulidade da lei inconstitucional, declaração de inconstitucionalidade sem pronúncia de nulidade, interpretação conforme à Constituição, o "apelo ao legislador" e a declaração de constitucionalidade da lei. Noutro grupo as decisões do Supremo Tribunal Federal no controle abstrato de normas: declaração de nulidade da lei, a interpretação conforme à Constituição, a declaração de constitucionalidade das leis, a declaração de inconstitucionalidade sem pronúncia de nulidade e a declaração de inconstitucionalidade de caráter restritivo ou limitativo (MENDES, 2005, p. 252-400).

${ }^{4}$ As decisões de declaração de inconstitucionalidade de caráter restritivo ou limitativo são aquelas referentes à modulação temporal de seus efeitos, que ao reconhecer a nulidade da norma, determina que seus efeitos passem a valer depois da publicação da decisão a eles inerente, em momento fixado pelo tribunal, nos termos do artigo 27 da Lei 9.868/1999. Já as decisões de declaração de inconstitucionalidade sem pronúncia de nulidade são aquelas que reconhecem a desconformidade conteudística do texto legislativo face à Constituição, porém não determina a sua extirpação do ordenamento jurídico, sob o argumento de que sua ausência acarretaria maiores danos que sua manutenção, ainda que dissociada dos preceitos constitucionais (MEYER, 2008, p. 132). Relativiza-se, pois, o binômio constitucionalinconstitucional porque, se assim fosse, seria causada uma situação jurídica insuportável ou grave perigo ao erário do Governo (SAMPAIO, 2001, p. 172). Quanto a essa última modalidade de decisão, cumpre destacar que se reconhece, diante de atual situação/contexto, a constitucionalidade da lei ou dispositivo de lei, todavia, o faz com fulcro em razões não jurídicas (políticas ou pragmáticas). (MEYER, 2008, p. 138) e (SAMPAIO, 2001, p. 175). Ora, percebe-se que os atos decisórios classificados como sentenças transitivas ou transacionais são per se perplexos e eivados de ilegitimidade. Em primeiro lugar, ao supor a possibilidade de transacionar-se com a supremacia da Constituição, que é uma conquista histórico-teórica da humanidade, do ponto de vista do alvedrio de alguns Ministros da Suprema Corte. Em segundo lugar, e correlatamente a isso, para tanto, decisões desse tipo são sustentadas por razões não jurídicas, comumente numa simbiose entre argumentos de política, pragmáticos e valores (MEYER, 2008, p. 80), retoricamente encobertados pelos rótulos da "segurança jurídica ou excepcional interesse social", para usar as expressões do artigo 27 da Lei 9868 de 10 de novembro de 1999, tidos como "fundamentos constitucionais" (MENDES, 2009, p. 32) a despeito de suas vaguezas conceituais e não explicitaçãotematização teórica. 0 que se vê é que tais decisões atendem aos anseios privatísticos do Executivo brasileiro, distorcidos, então, da constitucionalidade vigorante (SOUZA CRUZ, 2004, p. 356). 
ISSN 1981-3694

(DOI): $10.5902 / 1981369419761$

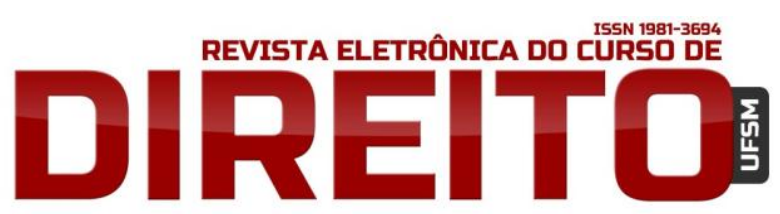

AS DECISÕES JUDICAIS NO CONTROLE DE CONSTITUCIONALIDADE E A SUA EFICÁCIA VINCULANTE NO ESTADO DEMOCRÁTICO DE DIREITO

além da data da publicação do ato decisório em questão, por meio da técnica de modulação de efeitos temporais, nos termos do artigo 27 da Lei 9.868/1999. Ora, esses proferimentos decisórios são per se conteudisticamente ilegítimos, o que impede de aceitá-los, quer em controle difuso quer em concentrado. Muito menos atribuir-lhes eficácia vinculante. Logo, para que uma decisão sirva de parâmetro para a apreciação de outras demandas judiciais precedente judicial -, deve ela, primeiramente, mostra-se legítima do ponto de vista de ser consentânea com o Direito positivo, especialmente com a Constituição.

Com isso, será feita uma análise apenas a acerca das decisões interpretativas e modificativas, dialogando com seus conteúdos, além de apresentar uma leitura hermenêutica a respeito da pretensão de thes conferir eficácia vinculante.

Segundo Emílio Peluso Neder Meyer, as decisões interpretativas têm o propósito de limitar a incidência normativa de determinado texto legal, cujo conteúdo constitucional fora colocado em dúvida. E partir da classificação aqui adotada, a decisão será considerada uma interpretação conforme à Constituição, quando fixar sentido a norma que seja adequado aos preceitos constitucionais. Por outro lado, será uma declaração de nulidade parcial sem redução de texto quando afirmar que é preciso especificar o âmbito de incidência da norma para alcançar determinado grupo de pessoas ou situações, não especificadas no texto redacional da norma, a fim de considerá-la constitucional. O autor também esclarece que nessas duas hipóteses a jurisdição desenvolve "uma atividade interpretativa como definidora da possibilidade ou não de conveniência da norma inquinada com a Constituição" (MEYER, 2008, p. 40). Significa dizer que dentre os inúmeros sentidos que se possa abstratamente atribuir a certo texto legal, um deles é qualificado como constitucional. Outra possibilidade é exemplificar aqueles que devem sucumbir face aos preceitos constitucionais. Ambas as hipóteses, portanto, implicam na redução "do campo de incidência original dos elementos normativos tipológicos" (SOUZA CRUZ, 2004, p. 252) ${ }^{5}$.

Explicitando essas duas modalidades de decisões referentes ao controle da constitucionalidade democrática das leis, pode-se dizer que o ato decisório que expressa uma interpretação conforme à Constituição declara a constitucionalidade da lei ou dispositivo normativo que se questionou, mas, por outro lado, fixa qual interpretação, dentre as possíveis, mostra-se consentânea com os preceitos constitucionais. É oportuna, portanto, "sempre que determinada disposição legal oferecer diferentes possibilidades de interpretação, sendo algumas

\footnotetext{
${ }^{5}$ Ademais, destaca-se que ao se expressar uma interpretação conforme à Constituição se introduz uma cláusula de exceção ou especificação no âmbito de incidência normativa (SAMPAIO, 2001, p. 164-165).
} 
ISSN 1981-3694

(DOI): $10.5902 / 1981369419761$

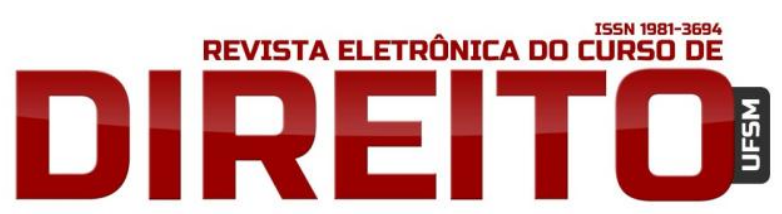

AS DECISÕES JUDICAIS NO CONTROLE DE CONSTITUCIONALIDADE E A SUA EFICÁCIA VINCULANTE NO ESTADO DEMOCRÁTICO DE DIREITO

delas incompatíveis com a própria Constituição” (MENDES, 2005, p. 287). José Adércio Leite Sampaio diz que a modalidade de decisão em questão consiste em "exclusão de interpretações inconstitucionais da norma impugnada e a sua redução ao único significado constitucional" (SAMPAIO, 2001, p. 163).

A propósito, cumpre, antes de tudo, infirmar-se a qualquer tentativa de fazer da interpretação conforme à Constituição, quando pronunciada pelo Supremo Tribunal Federal, a última palavra a respeito de textos legais na perspectiva da Constituição Federal. 0 efeito que tal decisão pode atingir é ser a base de orientação da interpretação de todos aqueles possíveis intérpretes do texto constitucional, nunca podendo fechar o seu círculo. (MEYER, 2008, p. 56) Isso porque ter "competência para declarar se uma lei é ou não conforme à Constituição não significar definir, de uma vez por todas, a interpretação última desta" (MEYER, 2008, p. 64).

Um exemplo ${ }^{6}$ que pode ser retirado da prática brasileira de decisão que enuncia uma interpretação conforme à Constituição é o acórdão relativo ao Habeas Corpus 110.844- Rio Grande do Sul, de relatoria do Ministro Ayres Britto, oportunidade em que o conteúdo normativo do artigo 44 da Lei $n^{\circ} 11.343 / 2006$ fora objeto de arguição de inconstitucionalidade por via difusa (BRASIL, STF, 2012 (a)).

0 referido pleito de habeas corpus tem origem na prisão preventiva do paciente pela prática, em tese, do crime de tráfico de drogas, na data de 02 de abril de 2009. Oportunidade em que o paciente foi flagrado na posse de aproximadamente 100 gramas de crack e um revólver calibre 38 municiado com cartuchos do mesmo calibre.

Encaminhado o auto de prisão em flagrante delito para o juízo da $3^{\mathrm{a}}$ Vara Criminal da Comarca de Novo Hamburgo, Rio Grande do Sul, o qual foi homologado. Todavia, a prisão preventiva do flagrado não foi determinada, sob o argumento de ser desnecessária, pois o flagrante prenderia por si só. Sustentou-se que a manutenção do encarceramento do paciente era devida por que "delitos desta natureza têm, por si só, causado grande abalo à ordem pública, uma vez o tráfico de drogas é indutor da criminalidade, e com a soltura dos flagrados se coloca em risco a sociedade”. Ademais, afirmou que o crime de tráficos de drogas não admite a concessão de liberdade provisória (RIO GRANDE DO SUL, 2009).

\footnotetext{
${ }^{6}$ José Adércio Leite Sampaio menciona uma série de exemplos contido no repertório jurisprudencial do Supremo Tribunal de Federal, dentre os quais, um artigo de lei que ao afirmar que as modificações e novidades procedimentais penais não teriam incidência quando já iniciada a sua fase instrutória, teve que ter sua incidência reduzida, a fim de não se aplicar a casos em que as normas de conteúdo penal fossem mais favoráveis aos réus - ADInMC n. 1719/DF - (SAMPAIO, 2001, p. 164-166).
} 
ISSN 1981-3694

(DOI): $10.5902 / 1981369419761$

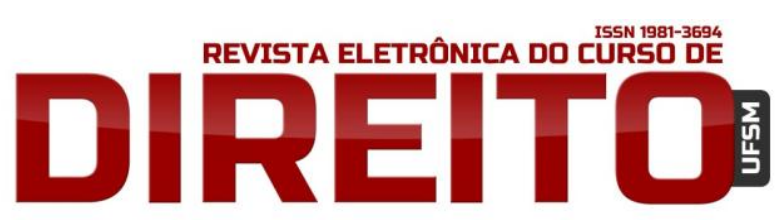

AS DECISÕES JUDICAIS NO CONTROLE DE CONSTITUCIONALIDADE E A SUA EFICÁCIA VINCULANTE NO ESTADO DEMOCRÁTICO DE DIREITO

Impetrou-se, então, habeas corpus, com requerimento de decisão liminar, perante o Tribunal de Justiça do Rio Grande do Sul, sustentado, em síntese, que a concessão da ordem se imporia tendo em vista o excesso de prazo na tramitação da persecução criminal. Além disso, asseverou-se que a manutenção da prisão afetaria negativamente princípios constitucionais do processo. 0 pleito de ordem liminar foi indeferido, mas no mérito a ordem foi concedida. 0 acórdão do Tribunal de Justiça do Rio Grande do Sul, em homenagem ao princípio da presunção de inocência, expressou entendimento de que somente a gravidade do delito, em tese, praticado não constitui fundamento idôneo para apoiar prisão (ou qualquer outra medida) de caráter cautelar, sendo necessária a explicitação dos requisitos elencados no Código de Processo Penal brasileiro. De conseguinte, para se prender cautelarmente uma pessoa é imprescindível que a decisão judicial aponte precisos e concretos elementos, fundamentando-os devidamente. De sorte que a prisão cautelar seja exceção, e não regra no curso do processo. Por último, foi lembrado que a Lei 11.464/2007, ao modificar a redação do artigo $2^{\circ}$ da Lei 8.072/90, afastou a impossibilidade de concessão de liberdade provisória para crimes hediondos e, consequentemente, prejudicou a aplicação do artigo 44 da Lei 11.343/2006 (RIO GRANDE DO SUL, 2009).

Em face ao mencionado acórdão, o Ministério Público do Estado do Rio Grande do Sul interpôs recurso especial perante o Superior Tribunal de Justiça, protestando pela reforma da decisão recorrida. Em suas razões recursais o Ministério Público argumentou que o conteúdo do acórdão impugnado ofenderia as normas do artigo 44 da Lei 11.343/2006 e 312 do Código de Processo Penal, pois a expressa vedação seria fundamento idôneo e suficiente para se indeferir pedido de liberdade provisória. Além do mais, sustentou que a entrada em vigor da Lei 11. 464/2007 não alterou o quadro normativo de proibição de concessão de liberdade provisória para o delito de tráfico de entorpecentes (BRASIL, STJ, 2011).

Nesse passo, a Quinta Turma do Superior Tribunal de Justiça, ao apreciar o aludido Recurso Especial (1.216.398/ Rio Grande do Sul 2010/0181052-7), de relatoria do ministro Adilson Vieira Macabau (desembargador convocado do Tribunal de Justiça do Rio de Janeiro), deu-lhe provimento para reestabelecer a decisão que havia indeferido a liberdade provisória da parte recorrida. Frisa-se que a decisão do Superior Tribunal de Justiça ancora-se no entendimento de que as Leis de números 8.072/1990 e 11.343/2006 guardam com o Código de Processo Penal uma relação de especialidade, sendo que a vedação de plano à concessão de liberdade provisória àqueles que respondam por crime de tráfico de entorpecentes seria razão idônea e suficiente: 
ISSN 1981-3694

(DOI): $10.5902 / 1981369419761$

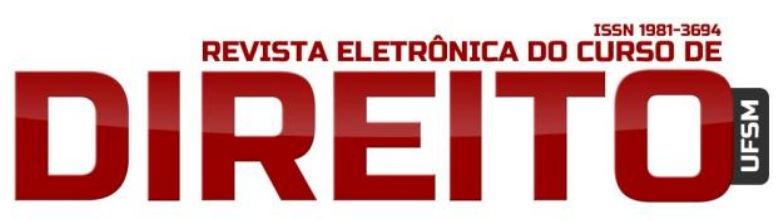

AS DECISÕES JUDICAIS NO CONTROLE DE CONSTITUCIONALIDADE E A SUA EFICÁCIA VINCULANTE NO ESTADO DEMOCRÁTICO DE DIREITO

[...] a Lei dos Crimes Hediondos e a Lei do Tráfico de Entorpecentes de 2006 demonstram relação de especialidade com o Código de Processo Penal, por disciplinarem através de critérios distintos a liberdade provisória. Todavia, é de sobrelevar-se que a primeira, ao elencar todos os tipos penais considerados hediondos faz-se genérica para com a segunda, já que se refere a um deles, qual seja o tráfico ilícito de entorpecentes. Diante do exposto, a expressa proibição legal à concessão do benefício de o réu responder a ação penal em liberdade, enquanto cumpre prisão cautelar, é razão idônea e suficiente para o indeferimento da medida (BRASIL, STJ, 2011).

Diante isso, foi impetrado habeas corpus perante o Supremo Tribunal Federal. Trata-se do Habeas Corpus 110.844, cuja relatoria é do ministro Ayres Britto. Aduziu-se que a decisão impugnada padece de ilegalidade, vez que alicerçada no absoluto impedimento de liberdade provisória descrito na norma do artigo 44 da Lei $n^{\circ} 11.343 / 200$, o que viola os preceitos normativos da inafastabilidade da jurisdição e da razoabilidade. Ademais, argumentou que o ato decisório impugnado careceria de fundamentação aceitável, ante a ausência de indicação dos requisitos para prisão cautelar. Em requerimento liminar, pleiteou proferimento de decisão determinando a imediata suspensão do ato questionado. No mérito, formulou pedido de concessão da ordem, a fim de tornar definitiva a liminar requerida, assegurando ao paciente o direito de aguardar a solução do processo penal em liberdade (BRASIL, STF, 2012(a)).

Vale mencionar que o artigo 44 da Lei 11.343/2006 preleciona que além de inafiançáveis, são insuscetíveis de sursis, graça, indulto, anistia e liberdade provisória os delitos relacionados à prática de traficância (artigos 33, caput e § 10, e 34 a 37 do mesmo diploma legal), vendandose, ainda, a conversão de suas penas em restritivas de direitos. Diante disso, o acórdão do Supremo Tribunal Federal abordou o seguinte problema: é cabível a concessão de liberdade provisória àquelas pessoas presas em flagrante delito de crime de tráfico de entorpecentes?

A resposta dada pelo acórdão é sim, porque, se assim não for, há que se admitir prisão cautelar como regra, e liberdade como exceção, o que afronta o princípio constitucional da não culpabilidade. Nessa perspectiva, interpretou-se o conteúdo normativo em questão conforme à Constituição, com objetivo de sedimentar que não se pode vedar, a priori, a concessão de liberdade provisória, além de outros direitos às pessoas envolvidas (investigadas, indiciadas, denunciadas, acusados e presos) em delitos relativos à prática de traficância, embora o crime continue sendo inafiançável. Ou seja, a não concessão de liberdade provisória há de ser precedida de análise das condições pessoais do indivíduo, bem como das particularidades do caso, tido como delituoso. E assim o fez com sustentação nos seguintes argumentos: 
[...] o fato em si da inafiançabilidade dos crimes hediondos e dos que the sejam equiparados parece não ter a antecipada força de impedir a concessão judicial da liberdade provisória, conforme abstratamente estabelecido no art. 44 da Lei $11.343 / 2006$, jungido que está o juiz à imprescindibilidade do princípio tácito ou implícito da individualização da prisão (não somente da pena). Pelo que a inafiançabilidade da prisão, mesmo em flagrante (inciso XLIII do art. $5^{\circ}$ da CF), quer apenas significar que a lei infraconstitucional não pode prever como condição suficiente para a concessão da liberdade provisória o mero pagamento de uma fiança. Noutros termos, a prisão em flagrante não pré-exclui o benefício da liberdade provisória, mas, tão-só, a fiança como ferramenta da sua obtenção (dela, liberdade provisória). Equivale ainda a dizer: se é vedado levar à prisão ou nela manter alguém legalmente beneficiado com a cláusula da afiançabilidade, a recíproca não é verdadeira. A inafiançabilidade de um crime não implica, necessariamente, vedação do benefício à liberdade provisória, mas apenas sua obtenção pelo simples dispêndio de recursos financeiros ou bens materiais. Tudo vai depender da concreta aferição judicial da periculosidade do agente, atento o juiz aos vetores do art. 312 do Código de Processo Penal. Daqui se segue que nem a inafiançabilidade exclui a liberdade provisória, nem o flagrante pré-exclui a necessidade de fundamentação judicial para a continuidade da prisão. Pelo que, nada obstante a maior severidade da Constituição para com os delitos em causa, só posso concluir que tal resposta normativa de maior rigor penal não tem a força de minimizar e muito menos excluir a participação verdadeiramente central do Poder Judiciário em tema de privação da liberdade corporal do indivíduo (BRASIL, STF, 2012 (a), p. 4-5).

Vê-se, em que pese a redação do artigo 44 da Lei no ${ }^{\circ}$ 11.343/2006 em seus conteúdos literais vedar a concessão de liberdade provisória, sursis, anistia, graça, indulto e a conversão das penas dos delitos relacionados à prática traficância em restritivas de direitos, em descompasso, portanto, com o princípio constitucional da não-culpabilidade no seu aspecto de norma de garantia ${ }^{7}$, impõe-se que sua interpretação, em conformidade à constitucionalidade brasileira, fixe-se o sentido de que não se pode negar abstratamente tais direitos a pessoas

\footnotetext{
${ }^{7}$ Além do aspecto de norma de garantia - o qual assegura a liberdade do cidadão, de sorte a impedir que quaisquer medidas ou prisões tenham caráter de satisfatividade antes de sentença penal condenatória passada em julgado -, o princípio da não-culpabilidade possui espectro de metodologia de tratamento digno, bem como um âmbito atinente ao ônus de prova. Quanto à metodologia de tratamento digno, valer ressaltar que o princípio em questão garante que os acusados ou investigados sejam tratados como sujeitos de direitos ao invés de mero objeto da persecução penal, de modo a não "coisificá-los", mediante o uso desnecessário de algemas, de uniformes do sistema prisional, exposição midiática ou quaisquer outros comportamentos diferente dos demais sujeitos do processo penal. Já quanto ao âmbito de incidência no que concerne ao ônus da prova, este determina que o cabe à acusação a comprovação de materialidade do crime (existência da infração penal), assim como da autoria (que o acusado concorreu para ela). Com isso, a defesa não precisa produzir provas para demonstrar a veracidade de sua argumentação. 0 acusado tem o direito de não colaborar com a produção de provas, até porque a Constituição (artigo $5^{\circ}$, inciso XLII) lhe assegura o direito ao silêncio. Ademais, havendo qualquer dúvida sobre o fato criminal, sua materialidade, o nexo de causalidade, elemento volitivo, tipicidade, ilicitude e culpabilidade, o acusado deve ser absolvido - artigo 386, incisos VI e VII do Código de Processo Penal (BARROS; MACHADO, 2011, p. 28-34).
} 
ISSN 1981-3694

(DOI): $10.5902 / 1981369419761$

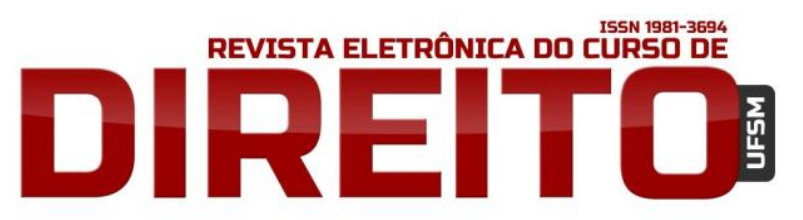

AS DECISÕES JUDICAIS NO CONTROLE DE CONSTITUCIONALIDADE E A SUA EFICÁCIA VINCULANTE NO ESTADO DEMOCRÁTICO DE DIREITO

GUILHERME CÉSAR PINHEIRO RICARDO NOBREGA

investigadas, acusadas ou em fase de execução penal, vale dizer, sem se ater às condições pessoais de cada uma delas e às particularidades do caso concreto ${ }^{8}$. Com isso, não se extirpa o

\begin{abstract}
${ }^{8}$ É oportuno registrar que, posteriormente ao comentado acórdão da Segunda Turma do Supremo Tribunal Federal, este tribunal apreciou novamente a constitucionalidade do citado artigo 44. Isso ocorreu no interior do acórdão relativo ao Habeas Corpus 104.339/São Paulo, de relatoria do ministro Gilmar Mendes. Destaca-se que a mencionada pretensão de habeas corpus tem origem na prisão em flagrante de uma pessoa pela prática do delito descrito no art. 33, caput, c/c 40, III, ambos da Lei 11.343/2006. Ao ser flagrada, em 25 de agosto de 2009, nas proximidades de escolas públicas estaduais, mantendo em guarda e em depósito na sua residência, 27,3 gramas de cocaína, acondicionadas em sessenta e duas cápsulas de cocaína em pó, 6,7 gramas de crack em forma de uma pedra, 73,5 gramas de cocaína em pó divididas em duas porções, e 4,9 quilos de cocaína divididos em cinco "tijolos". Foram ainda apreendidas, na ocasião, duas balanças de precisão e R\$ 44.877,00 em espécie. Sublinha-se que, na data de sessão de julgamento do writ em questão, o paciente encontrava-se encarcerado há mais de 33 meses, o que lhe daria direito à progressão de regime cumprimento de pena, eis que foi condenado a 7 (sete) anos e 6 (seis) meses de reclusão e a 750 dias multa. A aludida prisão em flagrante ensejou formulação de pedido de relaxamento da prisão em flagrante e/ou a concessão de liberdade provisória, o qual restou indeferido pelo Juízo da

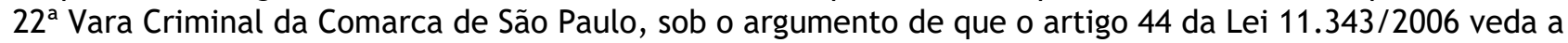
concessão de liberdade provisória em tal situação. Impetrou-se, com isso, habeas corpus perante o Tribunal de Justiça do Estado de São Paulo, sustentando a concessão da ordem na ausência de fundamentação da decisão que indeferiu o pleito de liberdade provisória. 0 aludido tribunal estadual denegou a ordem, o que ensejou impetração de habeas corpus perante o Superior Tribunal de Justiça, que também denegou a ordem, considerando que a proibição da concessão de liberdade provisória aos autores do crime de tráfico ilícito de entorpecentes decorre de texto legal e de norma constitucional. Diante dessas decisões denegatórias de ordem, impetrou-se novo habeas corpus, agora perante o Supremo Tribunal Federal, sustentando, em síntese, que a vedação genérica e abstrata de liberdade provisória àqueles que se envolvam com delitos relativos à traficância (artigo 44 da Lei 11.343/2006) afeta negativamente os princípios não culpabilidade (no sentido de excepcionalidade de prisão e medidas cautelares), devido processo legal e razoabilidade. Salienta-se que foi requerido o proferimento de decisão liminar para conceder a ordem pleiteada, o qual foi deferido pelo relator ministro Gilmar Mendes, que no mérito confirmou a concessão da ordem. E assim o fez sob o fundamento teórico-normativo de que vedar a concessão de liberdade provisória é incompatível com o princípio constitucional da presunção de inocência e do devido processo legal, principalmente por transformar o cárcere cautelar em antecipação e pena. Consequentemente, a legitimidade de qualquer ato decisório criminal cautelar resta vinculada à sua fundamentação, exigindo-lhe indicação de elementos fático-jurídicos que indiquem a presença dos requisitos do artigo 312 do Código de processo pela. Nas palavras de Gilmar Mendes: "Tenho para mim que essa vedação apriorística de concessão de liberdade provisória (Lei n. 11.343/2006, art. 44) é incompatível com o princípio constitucional da presunção de inocência, do devido processo legal, entre outros. É que a Lei de Drogas, ao afastar a concessão da liberdade provisória de forma apriorística e genérica, retira do juiz competente a oportunidade de, no caso concreto, analisar os pressupostos da necessidade do cárcere cautelar, em inequívoca antecipação de pena, indo de encontro a diversos dispositivos constitucionais. A previsão constitucional de que o crime de tráfico de entorpecentes é inafiançável (art. $5^{\circ}$, XLIII) não traduz dizer que seja insuscetível de liberdade provisória, pois conflitaria com o inciso LXVI do mesmo dispositivo, que estabelece que ninguém será levado à prisão ou nela mantido quando a lei admitir a liberdade provisória, com ou sem fiança Nesse sentido, imperioso concluir que a segregação cautelar - mesmo nos crimes atinentes ao tráfico ilícito de entorpecentes - deve ser analisada tal qual as prisões decretadas nos casos dos demais delitos previstos no ordenamento jurídico, o que conduz à necessidade de serem apreciados os fundamentos da decisão que denegou a liberdade provisória ao ora paciente, no intuito de verificar se estão presentes os requisitos do art. 312 do CPP que rege a matéria". Com apoio nessas razões o Pleno do Supremo Tribunal Federal declarou, incidentalmente, a inconstitucionalidade da expressão "e liberdade provisória", constante no caput do artigo 44 da Lei 11.343/2006. (BRASIL, STF, 2012 (b)). Cumpre ainda aduzir que apesar a decisão do
\end{abstract}


ISSN 1981-3694

(DOI): $10.5902 / 1981369419761$

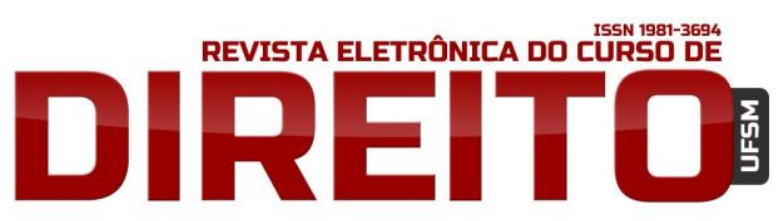

AS DECISÕES JUDICAIS NO CONTROLE DE CONSTITUCIONALIDADE E A SUA EFICÁCIA VINCULANTE NO ESTADO DEMOCRÁTICO DE DIREITO

GUILHERME CÉSAR PINHEIRO RICARDO NOBREGA

texto legal e sua norma do ordenamento jurídico, mas lhe é estabelecido uma diretriz de interpretação constitucional.

No que concerne à declaração de nulidade parcial sem redução de texto, esta é consequência de provimento relativo à pretensão de reconhecimento de inconstitucionalidade de lei ou ato normativo, em razão de seu âmbito de incidência não abarcar uma constelação de situações não especificadas na literalidade do texto legal, ou em vista de seu espectro de incidência não especificar quais as suas hipóteses de aplicação. Com isso, declara-se que o texto legal é nulo, caso seu espectro alcance tão-somente determinado grupo de pessoas ou situações, sem, contudo, ser necessário modificar seus conteúdos literais, ampliado, portanto, a todos os demais grupos de pessoas ou situações. Pode, por outro lado, mostrar-se imprescindível especificar qual é a situação em que o texto legal incide de maneira consentânea à Constituição. Assim, comumente, na prática da Corte Constitucional alemã as decisões pertinentes à declaração de nulidade parcial sem redução de texto são marcadas pela conjunção soweit, que na língua alemã significa “desde que” (MENDES, 2005, p. 261). É possível, pois, dizer que a declaração parcial de nulidade sem redução de texto incide sobre ou limites ou aquilo que foge aos ditames constitucionais, ao declarar inconstitucional a norma, caso seu âmbito não seja alcançado (SAMPAIO, 2001, 166). Ou seja, "a norma em apreço é constitucional, desde que se entendam determinadas disposições em certo sentido tido como constitucional” (BAHIA, 2006, p. 118).

A exemplificar, o acórdão que apreciou a pretensão (deduzida pela Procuradoria-Geral da República) de reconhecimento de inconstitucionalidade do artigo $1^{\circ}$ da Lei 9.536/1997 - Ação Direta de Inconstitucionalidade 3.324-7/Distrito Federal - mostra-se como expressivo de uma decisão de declaração parcial de nulidade sem redução de texto. O mencionado conteúdo normativo determina que as instituições de ensino são obrigadas a deferir requerimento de transferência (transferência ex officio ou obrigatória), entre instituições vinculadas a qualquer sistema de ensino, quando for requerido por servidor público federal civil ou militar estudante,

Supremo tenha expressamente declarado a inconstitucionalidade de parte do mencionado dispositivo, o efeito é o mesmo que de uma a interpretação conforme à Constituição. Isso porque determina que, embora não se admita que prestem fiança aqueles de respondam pela prática de crimes hediondos, é possível que thes sejam concedidos liberdade provisória, a depender das particularidades do caso concreto. Por último, cabe anotar que o Habeas Corpus em questão tramitou originalmente perante a Segunda Turma do Supremo Tribunal Federal. No entanto, foi transferido para o Plenário, com o fito de afastar a divergência entre as duas turmas do tribunal sobre o tema e, por conseguinte, imprimir uniformidade decisória a respeito ao cabimento ou não de liberdade provisória àquelas pessoas envolvidas com os crimes de tráfico de drogas. 
ISSN 1981-3694

(DOI): $10.5902 / 1981369419761$

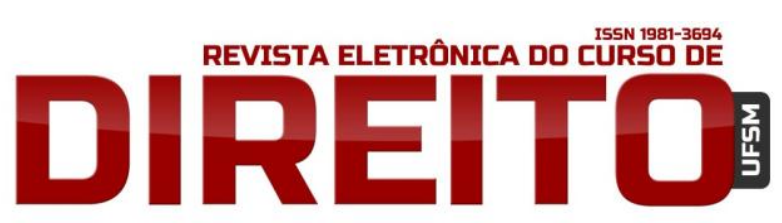

AS DECISÕES JUDICAIS NO CONTROLE DE CONSTITUCIONALIDADE E A SUA EFICÁCIA VINCULANTE NO ESTADO DEMOCRÁTICO DE DIREITO

GUILHERME CÉSAR PINHEIRO RICARDO NOBREGA

ou seu dependente, caso tal requerimento tenha como motivo comprovada remoção ou transferência de ofício. Exige-se também que a transferência do serviço acarrete mudança de domicílio para o município (ou para localidade mais próxima de) onde se localize a instituição recebedora.

Diante disso, criou-se a possibilidade de egressos de instituições de ensino privadas se transferirem para instituições públicas, o que estaria em desarmonia com os preceitos constitucionais insculpidos nos artigos $5^{\circ}$, caput e inciso I; 37, caput; 206, inciso I a VII; 207, caput; 208, inciso V, da Constituição Federal ${ }^{9}$. Depreende-se do acórdão em análise, por exemplo, que no curso de Direito oferecido pela Universidade de Brasília, no de ano 2004, setenta e nove alunos ingressaram por transferência obrigatória, cinquenta deles originários de instituições particulares. Em 2003, o saldo foi de cento e onze estudantes militares transferidos. Logo, o ingresso de estudantes por transferência passou a ser a regra, e a entrada mediante vestibular a exceção. Em outras palavras, o privilégio tornou-se regra, e o mérito a exceção (BRASIL, STF, 2005 (a), p. 4).

A articulação argumentativa da citada pretensão de reconhecimento de inconstitucionalidade objetivou demonstrar que o tratamento diferenciado dispensado aos servidores militares estudantes ou a seus dependentes, na medida em que viabilizasse a transferência de um estabelecimento privado de ensino para outro público, implicaria exceção desproporcional. Em que pese seja reconhecido como acertado o direito de servidores militares (e seus dependentes estudantes) se transferirem de uma instituição de ensino para outra, quando formulem requerimento sob o fundamento de remoção ou transferência de ofício, porquanto isso viabilizar a continuidade dos estudos. Daí, não se legitimaria a possibilidade de se realizar transferência de um estabelecimento privado de ensino para uma instituição pública.

\footnotetext{
${ }^{9}$ Art. $5^{\circ}$ Todos são iguais perante a lei, sem distinção de qualquer natureza, garantindo-se aos brasileiros e aos estrangeiros residentes no País a inviolabilidade do direito à vida, à liberdade, à igualdade, à segurança e à propriedade, nos termos seguintes: I - homens e mulheres são iguais em direitos e obrigaçõ̃es, nos termos desta Constituição; Art. 37. A administração pública direta e indireta de qualquer dos Poderes da União, dos Estados, do Distrito Federal e dos Municípios obedecerá aos princípios de legalidade, impessoalidade, moralidade, publicidade e eficiência e, também, ao seguinte; Art. 206. 0 ensino será ministrado com base nos seguintes princípios: I - igualdade de condições para o acesso e permanência na escola; II - liberdade de aprender, ensinar, pesquisar e divulgar o pensamento, a arte e o saber; III - pluralismo de ideias e de concepções pedagógicas, e coexistência de instituições públicas e privadas de ensino; IV - gratuidade do ensino público em estabelecimentos oficiais; Art. 207. As universidades gozam de autonomia didático-científica, administrativa e de gestão financeira e patrimonial, e obedecerão ao princípio de indissociabilidade entre ensino, pesquisa e extensão; Art. 208. $\mathrm{O}$ dever do Estado com a educação será efetivado mediante a garantia de: $\mathrm{V}$ - acesso aos níveis mais elevados do ensino, da pesquisa e da criação artística, segundo a capacidade de cada um.
} 
ISSN 1981-3694

(DOI): $10.5902 / 1981369419761$

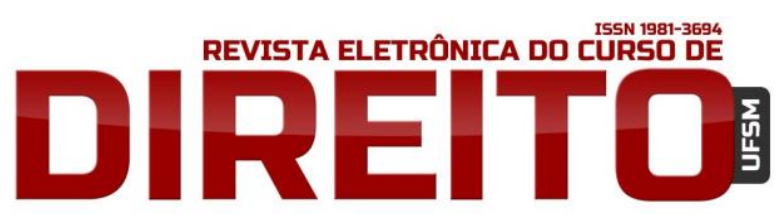

AS DECISÕES JUDICAIS NO CONTROLE DE CONSTITUCIONALIDADE E A SUA EFICÁCIA VINCULANTE NO ESTADO DEMOCRÁTICO DE DIREITO

Isso porque tal permissivo configuraria transgressão aos princípios constitucionais da igualdade, da moralidade e impessoalidade da administração estatal e da meritocracia como critério de ingresso às universidades públicas. Além disso, o propósito da norma do artigo $1^{\circ}$ da Lei de número 9.536/1997 (assegurar a continuidade dos estudos do servidor) restaria extrapolado. Destacou-se, ainda, que o ingresso em instituições privadas de ensino superior se daria por vias mais largas, em decorrência do grande número delas, em comparação à escassez de vagas no setor público. Consequentemente, permitir que um militar ou seu dependente, oriundo de universidade privada, se matricule em uma universidade pública sem prestar vestibular, acabaria por "burlar a igualdade" consagrada na Constituição em vigor, na medida em que privilegiaria um determinado grupo em detrimento ao restante da sociedade (BRASIL, STF, 2005 (a), p. 3-8).

Nesse quadro de ideias, conclui-se pela exigência de se atribuir sentido normativo ao texto do artigo $1^{\circ}$ da Lei número 9.536/1997 que seja consentâneo à constitucionalidade brasileira, bastando-se, para tanto, que se exija para a transferência obrigatória, o critério da congeneridade entre as instituições de ensino. Evoca-se como exemplo o artigo 99 da Lei $n^{\circ}$ $8.112 / 1990^{10}$, no que, relativamente aos servidores civis, prevê a matrícula em instituição congênere (BRASIL, STF, 2005 (a), p. 6-7).

Foi nesse contexto que se levantou dúvida sobre a constitucionalidade da norma do artigo $1^{\circ}$ da Lei $n^{\circ} 9.536 / 97$ no sentido de ser possível realizar a transferência ex officio de estudantes egressos de instituições de ensino privadas para instituições públicas, nas condições descritas no mencionado texto.

Nessa perspectiva, o acórdão em questão, ao apreciar o pleito de constitucionalidade do artigo $1^{\circ}$ da Lei $n^{\circ}$ 9.536/97, concluiu na direção de declará-lo inconstitucional, vez que a possibilidade de servidores públicos militares, ou seus dependentes se transferirem de instituições de ensino privadas para públicas, sem se submeterem a vestibular ou qualquer outro tipo de exame meritório, implica desigualdade, por favorecer essa categoria de servidores e seus dependentes, em detrimento do restante dos membros sociedade brasileira, especificamente no que se refere ao critério de acesso às universidades públicas, a saber: a meritocracia, em que pese haver razões jurídicas para se garantir a transferência de servidores públicos. Veja a seguinte passagem do acórdão em comento:

\footnotetext{
${ }^{10}$ Art. 99. Ao servidor estudante que mudar de sede no interesse da administração é assegurada, na localidade da nova residência ou na mais próxima, matrícula em instituição de ensino congênere, em qualquer época, independentemente de vaga.
} 
Se julgado procedente, chega-se, sem redução do texto, ao afastamento de regência tida por inconstitucional e esta é, justamente, de acordo com a peça inicial, a de viabilização, pelo artigo $1^{\circ}$ da Lei $n^{\circ} 9.536 / 97$, de transferência de instituição particular para pública. $O$ que se busca ver assentado é que, à luz dos textos constitucionais aludidos, a cláusula “... entre instituições vinculadas a qualquer sistema de ensino..." não alberga a transferência sem a observância necessária do caráter privado ou público das instituições envolvidas. [...] 0 artigo 99 da Lei $n^{\circ} 8.112 / 90$ e o $1^{\circ}$ da Lei $n^{\circ} 9.536 / 97$ repousam em razão de ser única a conveniência e, diria mesmo, a necessidade de ato da 'Administração Pública' (sic), de ato de interesse do Estado, não resultar em prejuízo na área sensível que é a da educação. A nova matrícula do servidor ou do dependente, seja ele civil ou militar, é, social e constitucionalmente, aceitável [...] 0 teor do artigo $1^{\circ}$ da Lei $n^{\circ}$ 9.536, de 11 de dezembro de 1997, presente a referência a instituições vinculadas a qualquer sistema de ensino, viabiliza entendimentos diversos. [...] 0 trato dos efeitos da transferência no campo da educação afigura-se desigual, favorecendo servidores militares em detrimento do grande todo, ou seja, do acesso à universidade pelo critério que norteia a realização do vestibular. É sabido que este, em instituição privada, não apresenta as mesmas dificuldades notadas no ingresso em instituição pública. Pois bem, abandonando-se a relação de causalidade própria aos diplomas legais, ter-se-á que, a persistir o artigo $1^{\circ} \mathrm{da}$ Lei $n^{\circ}$ 9.536/97, na óptica da Advocacia-Geral da União, o ato de transferência do servidor resultará em vantagem que não encontra justificativa, fugindo à simples razão de ser do texto - preservar a continuidade dos estudos. A matrícula logicamente sempre será pretendida na instituição pública, levando em conta não só a envergadura do ensino, como a própria gratuidade, absorvendo-se vagas que devem e precisam, de acordo com a Constituição Federal, ser oferecidas, presente o mérito dos candidatos, a toda a sociedade, viabilizando-se a participação igualitária em disputa que hoje é acirrada, ante a situação precária do ensino público, notada a flagrante escassez de vagas oferecidas. Sim, é consentânea com a Carta da República previsão normativa asseguradora, ao militar e ao dependente estudante, do acesso a instituição de ensino na localidade para onde é removido. Todavia, a transferência do local do serviço não pode se mostrar verdadeiro mecanismo para lograr-se a transposição da seara particular para a pública, sob pena de se colocar em plano secundário a isonomia - artigo $5^{\circ}$, cabeça e inciso 1 -, a impessoalidade, a moralidade na Administração Pública, a igualdade de condições para o acesso e permanência na escola superior, prevista no inciso I do artigo 206, bem como a viabilidade de chegar-se a níveis mais elevados do ensino, no que o inciso $V$ do artigo 208 vincula o fenômeno à capacidade de cada qual. Há mais. Sobressai a contrariedade ao princípio isonômico, no que vieram a ser tratados, de forma desigual, civis e militares, sem que o fator de discriminação mereça agasalho. Enquanto, à luz do artigo 99 da Lei $n^{\circ} 8.112 / 90$, a transferência de civis há de observar a similitude, a igualdade de situações, procedendo-se à matrícula em instituição congênere àquela de origem, os servidores militares têm algo que não lhes homenageia a postura elogiável notada na defesa do respeito a prerrogativas e direitos, ou seja, contam com verdadeiro plus, que é a passagem automática, em virtude da transferência, de uma situação onerosa e que veio a ser alcançada ante parâmetros singulares, para a reveladora de maior vantagem, presentes a gratuidade e a envergadura do ensino. Considerada a autonomia universitária, tomada em sentido maior, admite-se, é certo, a adequação do princípio da legalidade, a submissão à lei, mas indispensável é que se tenha disciplina calcada na proporcionalidade (BRASIL, STF, 2005 (a), p. 14-17), 
ISSN 1981-3694

(DOI): $10.5902 / 1981369419761$

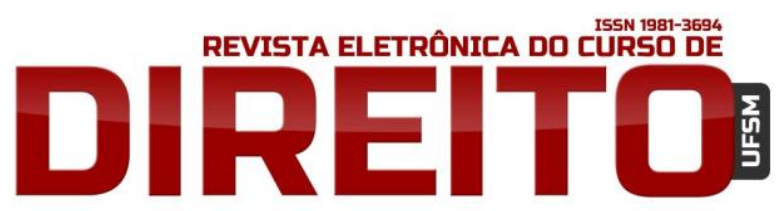

AS DECISÕES JUDICAIS NO CONTROLE DE CONSTITUCIONALIDADE E A SUA EFICÁCIA VINCULANTE NO ESTADO DEMOCRÁTICO DE DIREITO

Com fulcro nesses argumentos, sem reduzir a literalidade do artigo $1^{\circ}$ da 9.536/1997 assentou-se que a norma desse texto é constitucional desde que se observe a natureza pública ou privada da instituição de ensino de origem, assegurando a matrícula na sua congênere. Sinteticamente, a interpretação constitucionalmente adequada do aludido artigo estabelece que “dar-se-á a matrícula, segundo o artigo $1^{\circ}$ da Lei $n^{\circ} 9.536 / 97$, em instituição privada, se assim o for a de origem, e em pública, caso o servidor ou dependente for egresso de instituição pública” (BRASIL, STF (a), 2005, p.18).

Pela análise do acórdão em questão é perceptível que a interpretação nele expressa reconheceu que a norma do artigo $1^{\circ}$ da Lei 9.536/1997 é constitucional (desde que) se observe a natureza da instituição de ensino de origem (se publica ou privada), assegurando-se a matrícula na sua congênere. Foi reconhecida, então, a inconstitucionalidade do aludido dispositivo legal, em virtude da expressão legal "entre instituições vinculadas a qualquer sistema de ensino", permitir, em tese, a realização de transferências de servidores públicos militares de instituição de ensino superior particular para pública. No entanto, não se extirpa o referido artigo do ordenamento jurídico, porque o Estado Democrático de Direito rompe com a clássica e restrita acepção de jurisdição constitucional (controle de constitucionalidade) como "legislador negativo". Ao invés disso (e em complemento a isso) fixa um sentido que se mostre em harmonia com a Constituição do Brasil.

\section{SOBRE AS DECISÇOES MODIFICATIVAS (ADITIVAS E SUBSTITUTIVAS)}

As decisões modificativas são aquelas que deixam explícito aquilo que não ficou pela apreensão redacional do texto legal objeto de controle constitucional. Contudo, pode ser depreendido de preceitos principiológicos do ordenamento jurídico-constitucional. Especificamente, nesses atos decisórios a atividade hermenêutica consiste em adicionar ou substituir elementos tipológicos na norma criada pelo Legislador (SOUZA CRUZ, 2004, p. 252).

Decisões com tais características têm como pressuposto a noção de que a omissão da função legiferativa não ocorre apenas pela inexistência de ato normativo - omissão total -, mas também na hipótese de inadequação ou distorção no texto legal - omissão parcial - (MENDES, 2005, p. 316). Essa omissão na função legiferante é denominada por Michele Taruffo de “crise da legislação"11 (TARUFFO, 2001 (b), p. 19).

${ }^{11}$ Explica Michele Taruffo que a crise da legislação (crisi della legislazione) dá-se pelo fato de que a 
Ao se tratar das decisões modificativas, é forçoso salientar que ao se compreender que a jurisdição no Estado Democrático de Direito não desenvolve função criativa de direitos. Nesse eixo teórico-normativo, a jurisdição exerce uma atividade enunciativa dos conteúdos de textos legais (LEAL, 2009, p. 63), de modo que as decisões no controle de constitucionalidade não

produção legislativa tornou-se imensa, incontrolável, incoerente, fragmentária, variável, bem como pela circunstância das rápidas mudanças econômicas e sociais, o que faz com que a intervenção do Legislador seja quase sempre atrasada em respeito aos fatos que prende disciplinar. Com isso, verificam-se muitas "lacunas" (no sentido de falibilidade normativa) e antinomias no ordenamento jurídico. Acrescenta Michele Taruffo que as "lacunas" aparecem em razão da ausência de capacidade do legislador em adaptar-se com rapidez e eficácia às mudanças econômicas, sociais e culturais, enquanto as antinomias aumentam devido ao fato de que a legislação é constantemente controlada, no intuito de afastar suas contradições. Consequentemente, a tarefa de aplicação do Direito tornar-se, cada vez mais, perplexa, principalmente quando se procurar combater à arbitrariedade e à discricionariedade na jurisdição, ou seja, que o Direito seja legítimo no seu âmbito de criação e aplicação: “Ė noto a tutti che il modelo del legislatore símplice, chiaro, razionale e coerente, è tramontato da tempo (ammesso che sai mai esistito nella realtà, oltre che nei sogni dei filosofi). In tutti gli ordinamenti la produzione normativa è diventata imensa, incontrolabile, incoerente, pervasica, frammentaria, variabile. Inoltre, data la fortissima accelerazione del mutamenti economici e sociali, l'intervento del legislatore è sempre più spesso in ritardo rispetto all"evoluzione dei fatti che vorrebbe disciplinare. Tuttoi ciò è ormai parte dell1esperienza quotidiana di tutti gli ordinamenti, sicché non vale la pena di dilungarsi al riguardo. Va però sottolineato che questi fenomeni di crisi della legislazione incidono pesantemente sul ruolo istituzionale del giudice e sulle modalità concrete con cui questo ruolo può essere esercitato. Essi implicano un incremento fortissimo, in tutii i campi, delle lacune e delle antinomie del sistema. Le lacune aumentano perché il legislatore è sempre meno grado di regolare tempestivamente ed efficamente i fenomeni economici, sociali e culturali (gli esempi possono essere migliaia, dai problemi della bioetica a quelli della tutela del consumatore). Le antinomie aumentano perché una legislazione ormai sfuggita a qualsiasi controllo non può che contenere un numero crescente di contradizzioni interne di ogni tipo. In una situazione di questo, il giudice rimane tuttavia obligato a dicidere tutti i casi che gli vengono sottoposti, non potendosi rifugiare in un non liquet giustificato dall'incertezza e dalla confusione delle norme. Di conseguenza, egli dovrà comunque scegliere e formulare una regula juris per ogni caso che deve decidere, mas questa scelta sará tanto più arrisschiata - e potenzialmente arbitraria - quanto meno chiara è la situazione delle fonti del dirritto nell'ordinamento in cui giudice opera" (TARUFFO, 2001 (b), p. 19). Tradução: É do conhecimento de todos que o modelo de legislador simples, claro, racional e coerente, estabeleceu há muito tempo (se ele nunca existiu na realidade, nem nos sonhos dos filósofos). Em todos os ordenamentos a produção normativa tornou-se imensa, incontrolável, incoerente, penetrante [pervasiva], fragmentária, variável. Também, dada à fortíssima aceleração das mudanças econômicas e sociais, a intervenção do legislador é sempre mais frequentemente em atraso em respeito à evolução dos fatos que queriam disciplinar. Tudo isso já faz parte da experiência quotidiana de todos os ordenamentos, de modo que não vale a pena insistir nesta matéria. Ressalta-se que esses fenômenos de crise da legislação incidem fortemente sobre o papel institucional do juiz e as formas concretas que esse papel pode ser exercitado. Eles (tais fenômenos) implicam um forte aumento em todos os campos, das lacunas e das antinomias do sistema. As lacunas aumentam porque o legislador é cada vez menos capaz de adaptar-se rapidez e eficácia aos fenômenos econômicos, sociais e culturais (os exemplos podem ser mil, dos problemas da bioética àqueles de proteção dos consumidores). As antinomias aumentar, porque a legislação agora escapou de qualquer controle que não pode conter um número crescente de contradizzioni interna de cada tipo. Em tal situação, o juiz continua obrigado a dicidir todos os casos que lhe são submetidos, não sendo capaz de se refugiar em um non liquet justificado pela incerteza e confusão das regras. De conseguinte, ele [juiz] terá que escolher e formular uma norma jurídica [regula juris] para cada caso que deve decidir, mas essa escolha será tanto mais arriscada - e potencialmente arbitraria - quanto menos clara for a situação das fontes do direito no ordenamento em que o juiz trabalha [atua]". 
criam qualquer norma jurídica. No máximo, torna explícito algum conteúdo implícito no texto redacional da norma, mas já presente no ordenamento jurídico. Se assim não o fosse, a jurisdição extrapolaria seu âmbito de incidência, tornando-se, portanto, autoritária, ferindo, inclusive, a separação harmônica das funções estatais (HABERMAS, 1997, p. 321) ${ }^{12}$. Essa linha de reflexão, cumpre esclarecer, alicerça-se também na compreensão de Direito como integridade (DWORKIN, 2007), na qual é despiciendo um detalhamento no ordenamento jurídico de dada comunidade de princípios. Ainda que não haja o estabelecimento literal em textos legislativos de direitos aplicáveis a certos grupos de pessoas ou a situações, é possível inferir a normatividade desses do sistema constitucional.

E seguindo-se a classificação aqui adotada, duas são as modalidades de decisões modificativas, a saber: substitutivas e aditivas (MEYER, 2008, p. 70). 0 que individualiza as decisões aditivas é o aumento de incidência das disposições do contidas no texto legal, com o propósito de se atingir situações olvidadas (ou estrategicamente - propositalmente? - deixadas de lado) pelo órgão legiferante. Com isso, essas decisões dilatam o espectro de incidência, a fim de abranger situações não estabelecidas, prima facie, pelos conteúdos literais do texto legislativo. Dito de outra maneira, as decisões aditivas são caracterizadas por “[...] declarar inconstitucional um certo dispositivo por ter deixado de dizer algo ('na parte em que não previu...'), desde que a disposição omitida seja imposta pela lógica do sistema legislativo e constitucional [...]" (SAMPAIO, 2001, p. 168).

$\mathrm{O}$ acórdão do Supremo Tribunal Federal em que apreciou o pleito de Habeas Corpus 79.812-8/SP (BRASIL, STF, 2001) apresenta-se como ilustrativo de uma decisão aditiva. Essa garantia constitucional foi impetrada preventivamente em favor de José Corrissa Neto, a fim de

\footnotetext{
${ }^{12}$ A propósito, vale colacionar as ideias de Álvaro Ricardo de Souza Cruz, as quais tem apoio na teoria de Jürgen Habermas: "A decisão na via abstrata não é fruto de um discurso de fundamentação, tampouco uma lei, a despeito de sua decisão ser dotada de eficácia erga omnes. Não se trata de um novo princípio de universalização, visto não ter a Corte liberdade de tratamento de argumentos não normativos. Ao contrário, a Corte deve individualizar uma norma a partir do Ordenamento Jurídico. Ela não tem espaço para impor suas valorações / preferências pessoais, vez que a identidade da sociedade já fixou no processo constituinte os elementos éticos políticos da mesma. A despeito de sua generalidade e abstração, a decisão na via abstrata não é uma lei, ou seja, produto de um discurso normativo de justificação. Ao contrário, essa 'norma decisão', denominada no Direito italiano de rime obbligate, aproxima-se das decisões em processos coletivos do trabalho. Repita-se, nelas não há uma construção e sim um agir reconstrutivo das normas, compatível com o espaço criativo conferido pela hermenêutica contemporânea. Trata-se de uma soluzione costituzionalmente oblligata". Em virtude disso tudo, o autor arremata que "a legitimidade de uma decisão deve pautar-se segundo os limites da discursividade jurídica, sob pena de serem transformados em discursos anômalos de fundamentação, subvertendo a divisão de poderes e transformando o Judiciário, especialmente as Cortes Constitucionais, numa instância autoritária" (SOUZA CRUZ, 2004, p. 249 e 256).
} 
ISSN 1981-3694

(DOI): $10.5902 / 1981369419761$

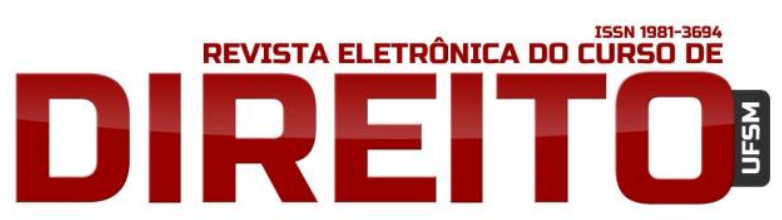

AS DECISÕES JUDICAIS NO CONTROLE DE CONSTITUCIONALIDADE E A SUA EFICÁCIA VINCULANTE NO ESTADO DEMOCRÁTICO DE DIREITO

assegurar-lhe a fruição de seu direito fundamental a não autoincriminação, perante depoimento à Comissão de Inquérito Parlamentar, apelidada de CPI do Narcotráfico, de maneira que não sofresse restrição no seu direito à liberdade, caso invocasse o seu direito fundamental de permanecer calado para se recusar a responder alguma indagação que tivesse o condão de lhe autoincriminar.

A impetração desse Habeas Corpus deu-se, primeiro, em razão de o artigo $5^{\circ}$, inciso LXIII da Constituição Federal, asseverar tão-somente (e expressamente) que aos "presos" serão assegurados o direito de permanecer calado. Assim, cogitou-se a possibilidade de investigados, acusados ou testemunhas não serem titulares de tal direito. E vale lembrar que as testemunhas têm o dever de dizer a verdade, não podendo se recusar a responder qualquer pergunta. Ademais, o paciente do Habeas Corpus em questão, como investigador de polícia em Campinas/SP, havia sido convocado à Comissão Parlamentar de Inquérito do Narcotráfico, inicialmente como indicado, mas lá retornando, posteriormente, na condição de testemunha. $\mathrm{E}$ em decorrência de atos arbitrários praticados por integrante desse órgão investigativoparlamentar, notadamente a não permissão da fruição do direito fundamental a não autoincriminação, afigurando real possibilidade de o paciente vir a ser preso, caso invocasse o mencionado direito de índole constitucional. Até porque outras pessoas em condições similares haviam sofrido constrangimento em seu direito à liberdade perante a referida Comissão Parlamentar de Inquérito.

Diante desse contexto, o aludido acórdão concedeu à ordem de habeas corpus preventivo e garantiu ao paciente, ainda que na condição de testemunha, fruir de seu direito ao silêncio e não ser prejudicado ao fazê-lo, isto é, não ser preso. E assim o fez, com fundamento na combinação teórico-normativa dos princípios constitucionais da não autoincriminação e nãoculpabilidade, porque este assegura, na sua compreensão como norma de tratamento, que o Estado, no exercício de suas funções persecutórias (incluindo a parlamentar), não trate os suspeitos, os indiciados, os denunciado e os réus, como se esses já houvessem sido declarados culpados e condenados por decisão preclusa, atingida pela coisa julgada:

Em suma: o direito ao silêncio constitui prerrogativa individual que não pode ser desconsiderada por qualquer dos poderes da República. Cabe enfatizar, por necessário - e como natural decorrência dessa insuprimível prerrogativa constitucional - que nenhuma conclusão desfavorável ou qualquer restrição de ordem jurídica á situação individual da pessoa que invoca essa cláusula de tutela que pode ser extraída de sua válida e legítima opção pelo silêncio. [...] No sistema jurídico brasileiro não, existe qualquer possibilidade de o Poder Público 
ISSN 1981-3694

(DOI): $10.5902 / 1981369419761$

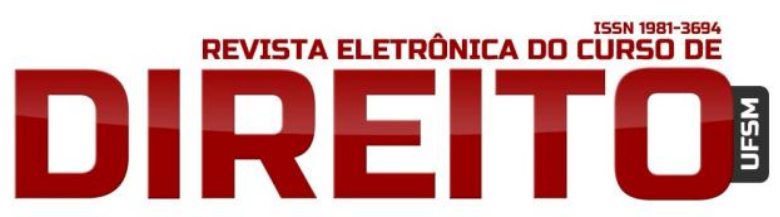

AS DECISÕES JUDICAIS NO CONTROLE DE CONSTITUCIONALIDADE E A SUA EFICÁCIA VINCULANTE NO ESTADO DEMOCRÁTICO DE DIREITO

GUILHERME CÉSAR PINHEIRO RICARDO NOBREGA

(uma Comissão Parlamentar de Inquérito, p. ex.), por simples presunção ou por meras suspeitas, reconhecer, sem prévia decisão judicial condenatória irrecorrível, a culpa de alguém. Na realidade, os princípios democráticos que informam o modelo constitucional consagrado na Carta Política de 1988 repelem qualquer comportamento estatal que transgrida o dogma de que não haverá culpa penal por presunção e nem responsabilidade criminal por mera suspeita. [...] Com efeito, esta Suprema corte já se pronunciou sobre a questão do necessário estatal aos direitos de qualquer pessoa contra quem é instaurado procedimento caráter investigatório (cuida-se de investigação policial ou trata-se de investigação parlamentar), firmando entendimento de que não permite reconhecer, fora das hipóteses na Constituição, a validade de medidas que possam gerar restrições jurídicas à esfera de autonomia individual do indiciado, ou, excepcionalmente, da própria testemunha. [...] Não constitui demasia enfatizar, neste ponto, que o princípio constitucional da não-culpabilidade [...] também consagra, em nosso sistema jurídico, uma regra de tratamento que impede o Poder Público de agir e se comportar em relação ao suspeito, ao indiciado, ao denunciado e ao réu, como se estes já houvessem sido condenados definitivamente por sentença do Poder Judiciário (BRASIL, STF, 2001, p. 209-213)

Vê-se que a decisão em comento adicionou elementos normativos tipológicos no ato de atribuir sentido ao texto do artigo $5^{\circ}$, inciso LXIII da Constituição. Particularmente, a extensão da aplicação do direito ao silêncio às pessoas que forem intimadas a depor em Comissões Parlamentares de Inquérito na condição de testemunha, desde que suas declarações tenham o condão de autoincriminar-lhes. Sublinha-se que isso se deu com fundamento em normas constitucionais (princípios da não autoincriminação e não culpabilidade). Entretanto, se assim não tivesse sido, o mencionado acórdão carecia de legitimidade democrática.

Por outro lado, as decisões substitutivas consistem, num primeiro momento, em reconhecer a nulidade do ato normativo e, posteriormente, acrescentar-lhe sentido normativo diverso e que seja consentâneo às normas constitucionais (MEYER, 2008, p. 70). Agora, o conteúdo da decisão não se restringe a repreender uma disposição "na parte em que não prevê" determinada hipótese, mas sim, além disso, "na parte em que prevê uma certa consequência ao invés de outra", desde que seja possível compreender isso intrinsecamente do sistema constitucional. Em outras palavras, "numa primeira parte, portanto, anula o conteúdo da disposição impugnada, para depois reconstruir a mesma disposição com conteúdo diferente" (SAMPAIO, 2001, p. 171).

O repertório jurisprudencial do Supremo Tribunal Federal não se apresenta como exemplificativo de decisões substitutivas, o que não impede que seja aqui analisada uma decisão (mesmo que interlocutória), atinente a tal categoria de ato decisório do controle de constitucionalidade, especialmente pelo seu conteúdo. 
ISSN 1981-3694

(DOI): $10.5902 / 1981369419761$

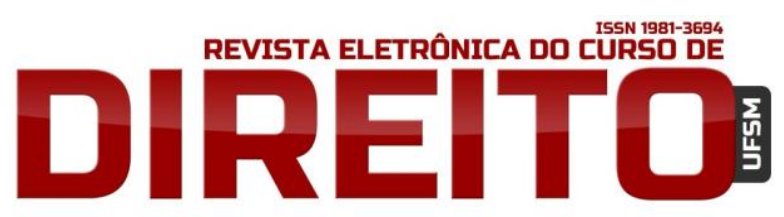

AS DECISÕES JUDICAIS NO CONTROLE DE CONSTITUCIONALIDADE E A SUA EFICÁCIA VINCULANTE NO ESTADO DEMOCRÁTICO DE DIREITO

Trata-se de uma decisão interlocutória liminar proferida pelo juízo da vara de infância e juventude da comarca de Joinville, do Estado de Santa Catarina, nos autos n 038.03.008229-0, referente à ação civil pública instaurada pelo Ministério Público em desfavor do Município de Joinville. Esse procedimento foi instaurado em virtude do aludido município não ter incluído entre suas prioridades orçamentárias e administrativas erário destinado à abertura de vagas e consequente matrícula de 2.948 crianças em lista de espera em educação infantil, ainda que houvesse sido feitas representações ao Secretário do Município, tendo-se, aliás, reconhecido tal demanda educacional na municipalidade. Ao contrário, o que se fez foi destinar a importância de $\mathrm{R} \$$ 1. 750.00,00 (um milhão setecentos e cinquenta mil reais) para a desapropriação de uma área, com o objetivo de construção de um estádio municipal de futebol. $\mathrm{E}$, segundo argumentação do Ministério Público, esse estádio favoreceria uma sociedade desportiva privada local, enriquecendo-a (SANTA CATARINA, 2003).

Em virtude disso, com sustentação teórico-normativa na Lei de Diretrizes e Bases da Educação, no Estatuto da Criança e do Adolescente e na Constituição Federal, foi aduzida pretensão no sentido de determinar a inclusão de montante suficiente para o oferecimento das 2.948 vagas para crianças em sistema de ensino educacional infantil, sem prejuízos daquelas que se encontravam já matriculadas. Requerendo-se, aliás, proferimento de decisão liminar para que isso fosse feito em 15 dias (SANTA CATARINA, 2003).

Ressalta-se que a despeito da Lei $n^{\circ}$ 9.494/97 vedar o deferimento de requerimento de decisões liminares de conteúdo satisfativo em desfavor de pessoas jurídicas de Direito Público (União, Estado, Município, só para citar os mais importantes), foi deferido tal requerimento, interpretando constitucionalmente a mencionada Lei. Isso com fundamento no Protocolo de San Salvador (complementar à Convenção Americana de Direitos Humanos), vigorante desde 1999, o qual impede que Estados (em qualquer de suas funções) pratique atos restritivos de Direitos Fundamentais, no caso, o Direito à Educação.

Em complemento, no que concerne ao argumento da não interferência do Judiciário na construção e fixação orçamentária do município, essa tese não foi acolhida. Primeiro, por se compreender que no Estado Democrático de Direito o Judiciário (jurisdição) como não passível às violações constitucionais, notadamente aquelas pertinentes a Direitos Fundamentais, o que o autoriza verificar a legitimidade, assim como legalidade dos atos administrativos do Executivo. Isso porque, nesse eixo, não se admite discricionariedade por quaisquer das funções estatais, nem mesmo o Executivo. Assim, por meio da jurisdição é legítimo analisar e requer a concreção 
de Direitos e Garantias Fundamentais dos cidadãos. Nesse quadro de ideias, importa colacionar as conclusões expressas na decisão que ora se comenta:

Com efeito, o Poder Judiciário deve analisar a destinação de recursos públicos que desconsideram a prioridade absoluta prevista no ECA, reordenando e exigindo que os investimentos públicos sejam feitos em conformidade com a Constituição Federal. A liberdade do administrador público em Construir Estádios de Futebol para utilização de agremiações privadas e mesmo com a manutenção de programas especiais, como a Escola do Teatro Bolshoi, pressupõe que a população carente esteja minimamente atendida. Não se pode aceitar a aplicação de dinheiro público com programas especiais, enquanto a pobreza continua sem escola, saúde e saneamento básico, dentre outros direitos sónegados. $\quad 0$ administrador público pode escolher suas prioridades discricionariamente somente depois de cumprir com o básico; enquanto não fizer, vedada se mostra a destinação de recursos para finalidades fomentadoras da iniciativa privada. E isso não precisava nem ser dito! [...] De sorte que está evidenciada com fortes tintas a fumaça do bom direito, consistente na obrigação do réu em cumprir as disposições legais antes indicadas no sentido de proporcionar o Ensino Fundamental às crianças de Joinville, bem como o perigo da demora avivado pela existência de pelo menos 2.948 crianças (número reconhecido pelo réu) desprovidas de Direito (Fundamental) à Educação. Dito de outra forma, a atuação do réu, diante das normas vigentes, viola o disposto na Constituição Federal (arts. $6^{\circ}$, 205; 208, IV, \$2 e 227); o Estatuto da Criança e Adolescente (arts. $4^{\circ}$; 53 ; e $54, \mathrm{I}, \$ 2^{\circ}$ ) e a Lei de Diretrizes e Base da Educação Nacional (Lei $9.394 / 96$, arts. $4^{\circ}$, I e 11, V) (SANTA CATARINA, 2003) (grifos no original).

Com fulcro nisso tudo, a decisão em questão, para além de apenas acrescentar elementos normativos tipológicos não previstos prima facie no texto legal, substitui um por outro, em razão de preferência lógico-jurídica, valer dizer, indicada na Constituição.

Referida decisão causou grande perplexidade no meio acadêmico ${ }^{13}$, isso em decorrência de seus conteúdos. É muito tênue e complexo abordar em termos hermenêuticos a questão de

\footnotetext{
${ }^{13}$ Lênio Luiz Streck teceu elogios aos conteúdos da decisão em questão, ao desenvolver críticas à teoria habermasiana. Particularmente, aduz que aparente (e suposto) conflito entre os direitos a "lazer-cultura" e à educação somente pode ser solucionado no caso concreto, com suas particularidades. Isso chama a atenção para um ponto muito importante: considerar que o ato decisório em comento foi correto do ponto de vista da constitucionalidade brasileira não significa asseverar que o direito à educação irá sempre sobrepor-se ao direito à cultura-lazer, nem o contrário, caso se entenda que tal decisão é ilegítima. Cumpre transcrever um trecho do comentário de Lênio Streck: "no caso em questão, não é (nem um pouco) irrelevante o fato de a verba estar destinada, originalmente, para um clube de futebol. Ao contrário: essa é a situação hermenêutica-concreta que baliza a solução, que, acima de tudo, tem como fundamento o art. 205 da Constituição do Brasil, o qual estabelece que a educação é direito de todos e dever do Estado e da família, tanto é que o ensino fundamental é obrigatório e gratuito, segundo o art. 54, I do Estatuto da Criança e Adolescente, cabendo ao município atuar prioritariamente no ensino fundamental e na educação infantil (art. 211, § $2^{\circ}$ e art. 60 das disposições transitórias da CF). Isso tudo aliado ao fato de que a Constituição estabelece, entre os objetivos fundamentais da República, a construção de uma sociedade justa e solidária, garantido o desenvolvimento, erradicando a pobreza e
} 
“ingerência” do Judiciário (jurisdição) no Legislativo e Executivo, realizando controle das políticas públicas e criação de leis. Repita-se que quaisquer adições ou substituições de elementos normativos tipológicos na fixação de sentido normativo ao texto legal há de ser feito com fundamentos no ordenamento jurídico.

\section{UMA LEITURA HERMENÊUTICA DA PRETENSÃO DE VINCULAÇÃO DAS DECISÇOES DO CONTROLE DE CONSTITUCIONALIDADE NO ESTADO DEMOCRÁTICO DE DIREITO}

Feitas essas considerações introdutórias atinentes às decisões do controle de constitucionalidade, notadamente sobre seus diferentes conteúdos, mostra-se necessário perscrutar-se na temática de atribuição de efeitos vinculantes a essas decisões. 0 que se quer, com isso, é estabelecer interlocução com os seus conteúdos. Assim, para além de uma análise excessivamente conceitual e abstrata, a fim de distinguir e classificar as decisões proferidas no controle de constitucionalidade das leis. Tem-se a preocupação mais com o âmbito e o conteúdo de cada uma delas, vez que, nesses casos, haverá sempre uma atribuição de sentido normativo (havidos como constitucionais) a textos legais. Ou seja, ao se atribuir maior relevância ao conteúdo das decisões desloca-se do campo da abstração e das multiplicidades de sentidos para o caso concreto e sua resposta adequada à Constituição.

reduzindo as desigualdades sociais (art. $3^{\circ}$ )" (STRECK, 2011, p. 178-179) (destaques do original). Importa ressaltar que as críticas de Lênio Streck dirigem-se especialmente ao posicionamento e aos comentários de Álvaro Ricardo de Souza Cruz, adepto da teoria habermasiana. É que Álvaro Ricardo de Souza Cruz questiona a circunstância de ser legítimo um magistrado decidir sobre a alocação de recursos orçamentários, ou se isso caberia ao povo diretamente ou indiretamente, por seus representantes (SOUZA CRUZ, 2006, p. 142 e ss). Isso se deve ao fato de que no eixo da teoria do discurso a noção de legitimidade das funções do Estado (Legislativa, Jurisdicional e Executiva ou Governamental) vincula ao espectro da argumentação de cada uma delas (Conferir nota de pé-de-página número 30, página 65), de modo que ao Judiciário não caberia reconstruir as razões das leis (neste caso, a Lei orçamentária), vez que esta teria sido discutida e votada "legitimamente" pelo Legislativo, nos limites de sua argumentação e de seu procedimento. Posto isso tudo, interessante salientar (em complemento às considerações de Lênio Streck, acima colacionada) que, no caso em questão, foram feitas representações ao Secretário do Município, informando sobre o déficit de vagas na educação infantil, com a finalidade de que este tomasse as devidas providências para sanar tal problema. No entanto, nada foi feito pelo Secretário do Município de Joinville. Diante disso, percebe-se que alguns atos extrajudiciais foram praticados antes de se intentar com a mencionada ação civil pública. Ou seja, não fossem a discricionariedade e a arbitrariedade de certos agentes públicos, não teria sido necessária valer-se do processo como meio para a efetivação de direitos fundamentais dos cidadãos. Portanto, a decisão em questão, mostra-se adequada à Constituição, principalmente pelos seus fundamentos constitucionais, que passaram longe da concepção axiológica. 
ISSN 1981-3694

(DOI): $10.5902 / 1981369419761$

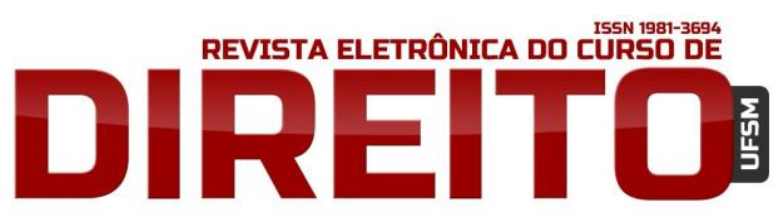

AS DECISÕES JUDICAIS NO CONTROLE DE CONSTITUCIONALIDADE E A SUA EFICÁCIA VINCULANTE NO ESTADO DEMOCRÁTICO DE DIREITO

Mostra-se muito mais proveitoso e interessante fazer uma análise crítica da "real decisão" (aquela que já foi proferida), sobretudo considerando as particularidades do caso concreto, do que analisar abstratamente as classificações conceituais de cada uma de suas modalidades. Não é possível dizer se uma decisão é constitucionalmente adequada antes que ela seja proferida.

Nessa perspectiva, é que se pretende dialogar com a pretensão de vinculação de decisões judiciais, a pretexto conferir certeza e segurança jurídica ao Direito, além de dar concretude à igualdade da atividade jurisdicional (uniformização decisória). Isso não pode, todavia, de maneira alguma, afastar o ponto fulcral da jurisdição, qual seja, a sua legitimidade.

O ponto de partida para a reflexão que ora se propõem é no sentido de que tanto os textos legais quanto as decisões judiciais (quer sejam proferidas em sede controle difuso, quer em concentrado) estão bem longe de eliminar totalmente os problemas modernos de indeterminação da interpretação jurídica. Muito pelo contrário, ao se solucionar um ou mais problemas, certamente, outros serão criados, não sendo possível prevê-los em sua totalidade. Isso faz com que a segurança jurídica na decisão judicial seja deslocada de sua previsibilidade para sua construção participada entre aqueles que serão atingidos pelos seus efeitos (BAHIA, 2006, p. 129)

Para tanto, parte-se dos referenciais teóricos do processualismo democrático (NUNES, 2009) e de uma hermenêutica que assegure igual direito de interpretação, propiciando que a Constituição seja interpretada por todos, não podendo haver qualquer fechamento ou engessamento de seu círculo de intérpretes. É indispensável, com isso, que se responda ou, pelo menos, se encaminhe para a solução desta pergunta: Sob a égide do Estado Democrático de Direito é legítimo admitir que o conteúdo de uma decisão do Supremo Tribunal Federal não possa ser "revisto" por outros órgãos do Judiciário, mesmo que haja razões teórico-normativas para fazê-lo?

Como hipótese, afirma-se que não é possível apostar no Supremo Tribunal Federal como intérprete único da Constituição, a pretexto de ser ele, supostamente, legitimado a dizer o que é constitucional ou inconstitucional, sob o auspício de ser o “guarda da Constituição". Não é legítimo estabelecer limites ao circulo de intérpretes da Constituição. Todo aquele que vive no contexto de aplicação da norma é potencialmente um intérprete, na medida em que é destinatário de seus efeitos jurídicos. Lembra-se que não é só Supremo Tribunal Federal que vive no contexto de aplicação da norma e não tem o monopólio da interpretação constitucional. Os 
ISSN 1981-3694

(DOI): $10.5902 / 1981369419761$

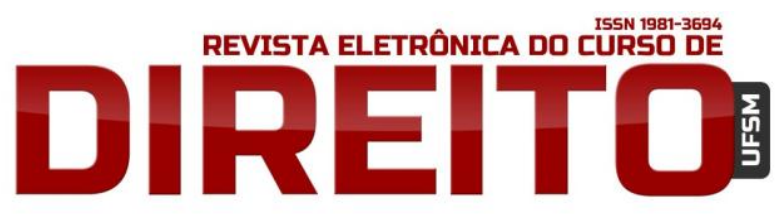

AS DECISÕES JUDICAIS NO CONTROLE DE CONSTITUCIONALIDADE E A SUA EFICÁCIA VINCULANTE NO ESTADO DEMOCRÁTICO DE DIREITO

GUILHERME CÉSAR PINHEIRO RICARDO NOBREGA

preceitos do Estado Democrático de Direito exige que o círculo de intérpretes da Constituição seja aberto a todos:

No processo de interpretação constitucional estão potencialmente vinculados todos os órgãos estatais, todas as potências públicas, todos os cidadãos e grupos, não sendo possível estabelecer-se um elenco cerrado ou fixado com numerus clausus de intérpretes da Constituição [...] Todo aquele que vive no contexto regulado por uma norma e que vive com este contexto é, indireta ou, até mesmo diretamente, um intérprete dessa norma. 0 destinatário da norma é participante ativo, muito mais ativo do que se pode supor tradicionalmente, do processo hermenêutico. Como não sãos apenas os intérpretes jurídicos da Constituição que vivem a norma, não detêm eles o monopólio da interpretação da Constituição (HÄBERLE, 1997, p. 12-15).

Assim, as decisões do Supremo Tribunal Federal, máxime àquelas referentes ao controle de constitucionalidade (interpretação conforme à Constituição, declaração de nulidade parcial sem redução de texto, além das sentenças modificativas - aditivas ou substitutivas), devem, sim, serem levadas em consideração pelos sujeitos processuais, mas não de maneira acrítica e irrefletida.

É oportuno anotar que apesar de a jurisprudência e seus precedentes, no atual contexto confluência entre o civil law e o common law, terem adquirido significativa importância na aplicação do Direito, não significa dizer é constitucionalmente adequada a importação sistemático-hierárquico-institucional do stare decisis do common law. É que, com isso, teria que se admitir que juízos hierarquicamente inferiores devam obedecer aos entendimentos firmados pelos juízos de superior hierarquia institucional. Se assim o fosse, no Brasil, os juízos de primeira instância deveriam decidir conforme seus respectivos tribunais (estaduais ou federais), esses últimos, em contrapartida, no mesmo sentido dos tribunais Superiores (Supremo Tribunal Federal, Superior Tribunal de Justiça ou Tribunal Superior do Trabalho), e esses dois últimos consentaneamente àquele. Isso evidenciara haver na sistemática brasileira autêntica teologia jurídico-decisória, porque sustentada na obediência a interpretação de textos legais, sobretudo a Constituição, realizadas, em última instância, pelo Supremo Tribunal Federal:

A caracterização desta barbárie teológica ganha escopo ainda maior quando alguns únicos especialistas/peritos reivindicam a exclusividade da competência para revelar a vontade divina nos textos religiosos, ou, a norma, nos textos jurídicos; decidindo quanto ao bem e ao mal, ao justo e ao injusto, ao verdadeiro e ao falso, ao permitido e ao proibido, ao possível e ao impossível, sem nenhum critério contextualizado autêntico, que no caso específico do Judiciário brasileiro seria o projeto constitucional vindo a cabo com a Constituição de 1988 (COPETTI NETO; MACHADO, 2009, p. 190) 
AS DECISÕES JUDICAIS NO CONTROLE DE CONSTITUCIONALIDADE E A SUA EFICÁCIA VINCULANTE NO ESTADO DEMOCRÁTICO DE

GUILHERME CÉSAR PINHEIRO RICARDO NOBREGA

Aceitar essa hierarquia sistemático-institucional é ficar preso à “dominação legítima legal"14 a que se refere Max Weber. Segundo a qual é devido obediência não à pessoa, mas à "regra estatuída", que, a seu turno, determina quem obedece e quem ordena, ao enunciar a regra ou ordem formalmente abstrata, sendo que “[...] o tipo daquele que ordena é o 'superior', cujo direito de mando está legitimado por uma regra estatuída, no âmbito de uma competência concreta [...]" (WEBER, 2004, p. 129) (destaque do original). É fácil compreender que isso não se adéqua aos preceitos do Estado Democrático de Direito, no qual a aplicação do Direito suscita comparticipação e policentrismo na atividade de interpretação dos textos legais (NUNES, 2009).

É, com isso, deixada de lado a proposta de uma "sociedade aberta de intérprete da Constituição" (HÄBERLE 1997, p. 12-15), que, por sua vez, é consentânea ao Estado Democrático de Direito, tratando-se, então, o controle de constitucionalidade das leis como uma questão de Estado (CATTONI DE OLIVEIRA, 2006, p. 177) e sob a perspectiva do observador (daquele que apenas descreve quais as decisões foram tomadas e não pergunta se ela é ou não adequada à Constituição, não perquiri a respeito de seus fundamentos). Portanto, essa assunção "estatalista" do controle de constitucionalidade das leis guarda umbilical relação com o positivismo - em especial aquele de matriz kelseniana, do ponto de vista da cisão interpretativa entre autêntica e não-autêntica ${ }^{15}$ - ao se criar um único intérprete da Constituição. Nessa direção, faz interessante denúncia Marcelo Cattoni de Oliveira, nos seguintes termos:

\footnotetext{
${ }^{14}$ Para Max Weber as formas puras de "dominação legítima" são apenas três que se entrelaçam. Elucida-se que para o autor dominação é compreendida como a possibilidade de obediência a certo comando. A dominação tradicional é caracterizada em decorrência da crença na santidade das ordenações e dos poderes senhoriais perceptíveis já há muito tempo. A obediência, nesse eixo, é calcada na dignidade pessoal do comandante, a qual é santificada pela tradição. Esta é que fixa os conteúdos das ordens, as quais se pressupõem válidas "desde sempre". Já quanto a dominação carismática, esta se funda na devoção afetiva à pessoa do senhor e a suas qualidades excepcionais (faculdades mágicas, revelações ou heroísmo, poder intelectual ou de oratória). A força e os conteúdos das ordens se impõem por essas qualidades excepcionais que o líder deter (WEBER, 2004, p. 128, 129, 131 e 134-135).

${ }^{15}$ Cumpre esclarecer a distinção empreendida por Hans Kelsen no que concerne à interpretação jurídica, cindindo-a em autêntica e não-autêntica. 0 autor, na estreita estrutural-enunciativa de sua "Teoria Pura do Direito", compreende o Direito como um sistema de normas escalonadas em regime hierárquico, no qual uma norma inferior encontra sua validade em outra norma hierarquicamente superior. Com efeito, ao se pretender fixar sentido a um texto legislativo, ou seja, interpretá-lo, é preciso fazer uma operação intelectual (cognitiva) que acompanha o processo de aplicação do Direito no seu progredir de um escalão superior para um escalão inferior. Uma vez, portanto, que existem, inegavelmente, indeterminações entre normas de diferentes escalões (Constituição em contraste com uma Lei ordinária), ou entre esta e um ato jurídico, a norma a ser aplicada é compreendida apenas como um quadro, uma moldura, onde se busca várias possibilidades (CATTONI DE OLIVEIRA, 2004, p. 126), exigindo-se que qualquer ato de aplicação da norma esteja em conformidade com tal moldura e, por conseguinte, de acordo com norma, razão pela qual existiriam, ao contrário, várias possibilidades corretas, desde que dentro das estabelecidas pela moldura. Nesse norte, é que se apresenta a diferença entre a interpretação realizada pelos órgãos estatais (funções administrativa, legislativa ou Judiciária) e a operada pelos cidadãos ou pela Ciência do Direito.
} 
A teoria que chamamos estatalista pode ser analisada a partir de uma crítica a uma de suas maiores representantes, a teoria kelseniana. Essa seria estatalista porque está fundada, antes de tudo, num positivismo jurídico que, ao contrário do que muitas vezes se afirmar, adequa-se ao paradigma do Estado Social, na medida em que instrumentaliza, através da noção de interpretação autêntica ou autorizada, a discricionariedade necessária ao desenvolvimento de políticas governamentais de impacto, cujo mérito nunca poderia ser conhecido pela Ciência do Direito (Cattoni de Oliveira, 1997; Carvalho Netto, 1997). Kelsen restringe, assim, a comunidade de intérpretes autorizados da Constituição aos órgãos jurídicos, não a estendendo a todo o público de cidadãos, o que leva a não diferenciar aquele que nega a força vinculante do comando por não reconhecer a sua objetividade, ou seja, seu fundamento de validade, o mero criminoso, que desobedece à norma sem apresentar razões intersubjetivamente aceitáveis, já que todos os dois assim se comportariam por sua conta e risco (Kelsen, 1987; 293). Ao assim conceber o processo de interpretação e aplicação do Direito como uma questão, em última análise, de decisões juridicamente autorizada ou institucionalizada, Kelsen inverte a lógica do controle de constitucionalidade privilegiando, mais que uma pretensão de validade dos comandos estatais, uma compreensão da dinâmica jurídica incompatível com o Estado Democrático de Direito que, fundado numa compreensão procedimentalista do Direito e da Política, parte não de um modelo fechado, quer das normas jurídicas, quer do seu círculo de intérpretes, mas aberto e

Diz-se não-autêntica a interpretação destes, e autêntica a interpretação realizada por aqueles. Com efeito, por meio da interpretação autêntica, um cidadão interpreta a norma a fim de verificar se o ato que pretender praticar será ou não conforme o direito, enquanto a Ciência do Direito descreve as possíveis possibilidades de aplicação da norma, ou seja, estabelece qual é a moldura interpretativa da norma. Noutro sentido, autêntica seria a operação intelectual pela qual o órgão jurídico aplicador ou executor da lei efetua a escolha entre os possíveis sentidos da norma dados pela moldura, estabelecidos pela interpretação não-autêntica. Contudo, afirma o Kelsen, a contrário senso, que o órgão aplicador ou executor (intérprete) poderia, por meio da interpretação autêntica (interpretação como ato de vontade), escolher livremente não somente um dos sentidos normativos arrolados pela interpretação não-autêntica (interpretação como ato cognoscitivo), isto é, moldura interpretativa do direito, mas qualquer outro sentido atribuível à norma, mesmo que não se situasse dentro moldura interpretativa (KELSEN, 2006, $p$. 387-394). A propósito, interessante dar destaque a pesquisa feita por Marcelo Andrade de Cattoni de Oliveira, frisando que Kelsen não pensava assim desde o início, vez que a expressão "interpretação autêntica" não é usada na primeira edição (1934) de sua “Teoria Pura do Direito". Tal expressão é textualizada, pela primeira vez, na edição francesa (1953), quando o autor no capítulo 10 discorre sobre a interpretação. Mas é na terceira edição (1960), mais especificamente no capítulo 8, que ocorre o giro decisionista kelseniano quando o conteúdo significativo da interpretação autêntica é ampliado (CATTONI DE OLIVEIRA 2001, p. 31-60). Mais sobre o tema, conferir (GRAU, 1996, p. 35-38). Daí ser fácil perceber a perplexidade que qualquer aproximação com a teoria da interpretação como ato de vontade causa quando se busca enunciar um Direito Processual comprometido em soçobrar o subjetivismo, arbitrariedade ou discricionariedade. Acrescenta-se que essa tentativa de engressamento e restrição do círculo de intérpretes da Constituição guarda restrita relação com a noção de jurisdição como centro de poder e da teoria do processo, na medida em que se compreendem as decisões vinculantes enquanto "aquelas que são proferidas pelas cortes formadas por homens considerados incapazes de falha, mas que emitem juízo de valor, muita das vezes, equivocado e incompatível com os fins sociais almejados pela coletividade. Em verdade, nada mais óbvio do que concluir pela possibilidade de decisões imutáveis e indiscutíveis (petrificadas), emitidas por grupo seleto de julgadores, que tenham efeito superior ao próprio ordenamento jurídico e a Constituição, quando se advoga a jurisdição como centro de poder e da teoria do processual." (PENNA, 2004, p. 21). 
ISSN 1981-3694

(DOI): $10.5902 / 1981369419761$

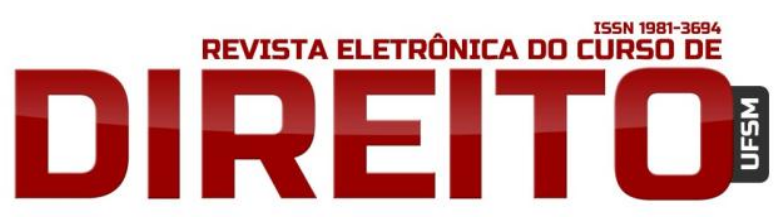

AS DECISÕES JUDICAIS NO CONTROLE DE CONSTITUCIONALIDADE E A SUA EFICÁCIA VINCULANTE NO ESTADO DEMOCRÁTICO DE DIREITO

fundado em princípios (CATTONI DE OLIVEIRA, 2006, p. 175) (destaque do original).

Acrescenta-se a isso, o fato de que uma decisão (do Supremo ou de qualquer outro tribunal) não é capaz de resolver “os problemas ínsitos” à interpretação jurídica, mesmo que seja correta do ponto de vista constitucional. Um acórdão não conseguirá, por hipótese, antever todas as possíveis situações de desrespeito aos princípios constitucionais da presunção de inocência, da não culpabilidade (no sentido de direito ao silêncio), da igualdade, da moralidade da administração estatal, da meritocracia como critério de acesso às universidades públicas, além do direito à educação - mencionando-se apenas aqueles preceitos analisados das decisões anteriormente comentadas. Assim, impossível afastar a mediação entre o conteúdo da decisão e o intérprete.

Em outras palavras, haverá sempre a necessidade de interpretação, quer de decisões, quer de textos legislativos. Aliás, muitas das vezes é indispensável o dispêndio de árduo esforço argumentativo por partes dos sujeitos processuais, com o fito de se chegar a uma resposta constitucionalmente adequada ao problema posto pela demanda judicial.

Para ilustrar essas ideias, toma-se como exemplo acórdão relativo ao Recurso Extraordinário176479-1/Rio Grande do Sul, relator do ministro Moreira Alves (BRASIL, STF, 1997). Tal decisão refere-se à seguinte situação.

Foi publicado edital de concurso público para admissão em Curso de Formação de agente penitenciário, não sendo estabelecida exceção com relação a servidor público, inclusive policial militar. Nessa oportunidade, instituiu ser necessário ter entre 21 e 35 anos de idade para se inscrever no certame. Isso acarretou o indeferimento da inscrição de Jânio Jacob Balbo, em vistas de ter, à época, 38 anos de idade. Diante disso, impetrou-se mandado de segurança perante o Tribunal de Justiça do Rio Grande do Sul, o qual concedeu a segurança, permitindo que impetrante se inscrevesse no concurso em questão.

Foi, então, manejado recurso extraordinário pelo Estado do Rio Grande do Sul protestando pela reforma da decisão recorrida, uma vez que seus conteúdos violariam o preceito normativo do artigo 37, inciso I da Constituição brasileira, ao desconsiderar o limite de idade fixado por lei estadual do Rio Grande do Sul para participação do referido concurso público.

O acórdão da Primeira Turma do Supremo Tribunal Federal, por sua vez, julgou procedente o Recurso Extraordinário 176479-1/Rio Grande do Sul, sob o fundamento de que é razoável e justificável estabelecer restrição quanto à idade mínima e/ou máxima para inscrição 
ISSN 1981-3694

(DOI): $10.5902 / 1981369419761$

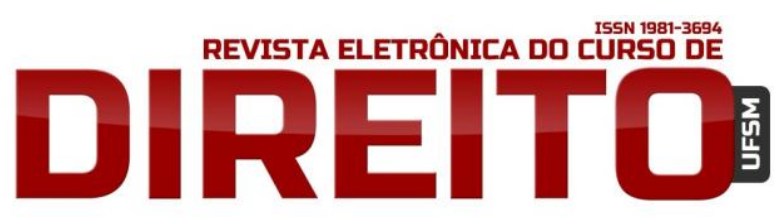

AS DECISÕES JUDICAIS NO CONTROLE DE CONSTITUCIONALIDADE E A SUA EFICÁCIA VINCULANTE NO ESTADO DEMOCRÁTICO DE DIREITO

GUILHERME CÉSAR PINHEIRO RICARDO NOBREGA

em concurso público, em razão da natureza do cargo. Frisa-se que no edital do aludido concurso, constou, entre as várias atribuições do cargo, as seguintes: 1) cuidar da disciplina e segurança dos presos; 2) fazer rondas periódicas; 3) fiscalizar o trabalho e o comprometimento da população carcerária; 4) providenciar a assistência aos presos; 5) verificar as condições de segurança física do estabelecimento; 6) conduzir viaturas de transportes de presos; 7) usar da responsabilidade inerente ao cargo solicitado, se possível ajudar policial na captura de presos evadidos, desde que tenha conhecimento da evasão e saiba o lugar que se encontra o evadido, ou venha a se deparar com ele; 8) fiscalizar a entrada e saída de pessoas e veículos no estabelecimento penais, incluindo execução de serviços corporais; 9) efetuar a conferência periódica da população carcerária, além de outras funções correlatas. (BRASIL, STF, 1997, p. 777-778).

Considerando essas atribuições, o ministro relator Moreira Alves fundamentou seu voto dos seguintes termos:

Como se vê, são funções de policiamento dentro de presídios e não funções burocráticas, exigindo-se, por isso mesmo, na segunda fase do concurso prova de aptidão física conforme programa, que não se confunde com a inspeção médica que é feita na terceira fase do mesmo concurso. Ademais, tratando-se de concurso para ingresso em curso de formação para função de natureza policial, não há, evidentemente, qualquer natureza discriminatório no estabelecimento de idade mínima e idade máxima para tal ingresso, até pela circunstância de que necessidade de agentes que, pelo menos, desde a fase inicial da carreira e durante um razoável período de tempo nela, tenham idade compatível com a aptidão física necessária para o exercício dessas funções, à semelhança do que ocorre com os policiais militares, para os quais a Constituição Federal (arts. 42 §§ 9 e 11) não impõe vedação para o estabelecimento de requisito de idade. Considero, pois, que este é um dos casos em que a limitação de idade - tanto a mínima quanto a máxima - é justificada pela natureza das atribuições do cargo não se the aplicando, portanto, a vedação do artigo $7^{\circ}, \mathrm{XXX}$, da Constituição Federal (BRASIL, STF, 1997, p. 7-8).

Pelo exposto, é possível concluir que a decisão ora comentada é expressiva de uma interpretação conforme à Constituição. Particularmente, no que se refere à permissão para que, por intermédio de leis, se estabeleça idade mínima ou máxima para acesso a cargos públicos, considerando-se a natureza das atribuições do cargo a ser preenchido, sem que isso implique ato discriminatório.

Inclusive, importa salientar que esse entendimento foi sumulado (súmula 683) pelo Supremo Tribunal Federal, nos seguintes termos: "O limite de idade para inscrição em concurso público só se legitima em face do art. $7^{\circ}, \mathrm{XXX}$, da Constituição, quando possa ser justificado pela 
ISSN 1981-3694

(DOI): $10.5902 / 1981369419761$

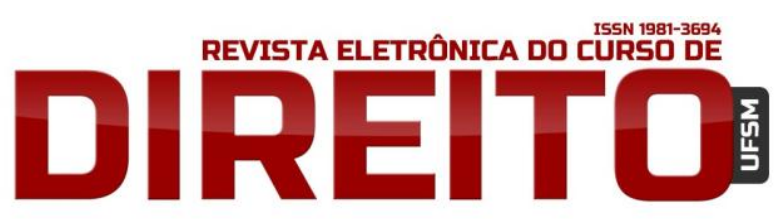

AS DECISÕES JUDICAIS NO CONTROLE DE CONSTITUCIONALIDADE E A SUA EFICÁCIA VINCULANTE NO ESTADO DEMOCRÁTICO DE DIREITO

natureza das atribuições do cargo a ser preenchido”.

Com isso, ao se considerar o citado acórdão do Supremo Tribunal Federal como adequando à Constituição, poderia cogitar-se que para alcançar a almejada certeza e segurança jurídica na interpretação do Direito, bastaria aplicar mecanicamente o conteúdo de tal decisão, principalmente após a edição do verbete sumular número 683. Mas, perceba que tanto a conclusão da decisão quanto o enunciado da citada súmula fazem menção a exigência de se justificar a imposição de limite de idade para inscrição em concurso público pela natureza do cargo a ser preenchido. Significa dizer, é imprescindível analisar uma situação fática concreta a fim de que se possa perquirir se é justificável ou não a imposição de limite de idade. Até porque são inúmeras e imprevisíveis as situações concernentes à limitação de idade para inscrição em concurso público e sua possível justificação em virtude da natureza do cargo. Fica fácil compreender como um enunciado genérico e abstrato não soluciona “os problemas" de interpretação do Direito.

Uma vez mais, ilustra-se tais ideias como a análise de uma decisão judicial. Trata-se, agora, de um acórdão da $1^{\text {a }}$ Câmara Cível do Tribunal de Justiça de Minas Gerais que apreciou razões recursais de apelação e realizou reexame necessário de número 1.0024.06.989651-2/002. A relatoria foi do desembargador Armando Freire. 0 caso é também referente a indeferimento de inscrição em concurso público. Desta vez, para o provimento de cargo de $2^{\circ}$ Tenente do Quadro de Oficiais de Saúde da Polícia Militar de Minas Gerais, sendo que foi formulado requerimento de inscrição para vaga de médico proctologista. E no edital do citado certame, foi estabelecido idade máxima de 35 anos para ingresso na carreira de $2^{\circ}$ Tenente de Quadro de Oficiais de Saúde da Polícia Militar de Minas Gerais (MINAS GERAIS, TJMG, 2008).

Diante disso, foi impetrado, perante o juízo da $2^{\text {a }}$ Vara da Fazenda Pública e Autarquias da Comarca de Belo Horizonte, mandado de segurança com requerimento de decisão liminar para deferir a inscrição do impetrante no concurso em questão. Em síntese, o pleito para concessão da segurança foi sustentado, teórica e normativamente, na argumentação de que o limite de idade máxima para ingresso na mencionada carreira, qual seja, 35 anos, é discriminatório e representa afronto aos princípios constitucionais da igualdade e razoabilidade. Justificou-se essa assertiva no fato de que as funções inerentes ao cargo pretendido $\left(2^{\circ}\right.$ Tenente de Quadro de Oficiais de Saúde da Polícia Militar de Minas Gerais) não se relacionam com o exercício de atividade tipicamente militar. Portanto, o impetrante possuiria o direito líquido e certo de efetivar sua inscrição no concurso. Ao final, formulou-se requerimento para o proferimento de decisão interlocutória (medida liminar) que assegurasse o direito de o 
ISSN 1981-3694

(DOI): $10.5902 / 1981369419761$

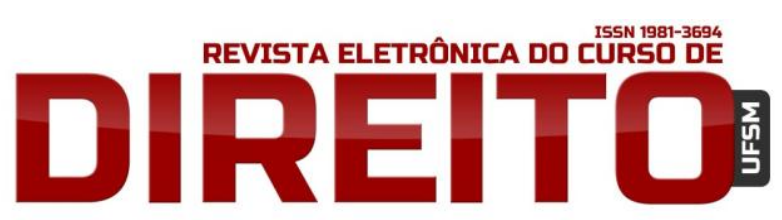

AS DECISÕES JUDICAIS NO CONTROLE DE CONSTITUCIONALIDADE E A SUA EFICÁCIA VINCULANTE NO ESTADO DEMOCRÁTICO DE DIREITO

GUILHERME CÉSAR PINHEIRO RICARDO NOBREGA

impetrante fazer sua inscrição no concurso. No mérito, protestou pela concessão definitiva da segurança, garantindo ao impetrante o direito de participação regular em todo o processo seletivo e, se aprovado, a investidura no cargo almejado (MINAS GERAIS, TJMG, 2008).

Em sentença acolheu-se integralmente a pretensão do impetrante concedendo-lhe a segurança, a fim de autorizar a sua inscrição e participação em todo o certame. Sentença essa sustentada nos seguintes argumentos: 1) É indispensável que ao se estabelecer requisitos necessários ao preenchimento dos cargos públicos, paute-se pelos princípios da razoabilidade e da proporcionalidade, com o objetivo de não se criar exigências discriminatórias. 2) No caso, pela circunstância de o exercício das funções de médico proctologista não exige o vigor físico próprio das atividades militares, não havendo qualquer óbice à ocupação da vaga por candidato que possua idade superior a 35 anos, sendo totalmente descabida e, portanto, discriminatória a exigência do edital (MINAS GERAIS, TJMG, 2008).

Nesse passo, o Estado de Minas Gerais interpôs recurso de apelação, em síntese, argumentou que duas são as razões para imposição do limite de idade para inscrição no concurso promovido pela Policial Militar de Minas Gerais, ambas respaldadas no princípio da isonomia e no princípio da razoabilidade, qual seja: a natureza da função militar, bem assim o tempo de serviço prestado pelo oficial, sendo certo que a transferência para a reserva dá-se por imposição legal aos 65 anos (MINAS GERAIS, TJMG, 2008).

Em fim, o acórdão em comento tem como objeto o reexame necessário da aludida sentença. Salienta-se que acórdão confirmou o conteúdo da sentença recorrida. Assegurou-se, com isso, o direito de o impetrante participar do certame e, inclusive sua nomeação, em vista de ter sido aprovado em $2^{\circ}$ lugar. Isso sob o fundamento de que a exigência de idade máxima de 35 anos para ingresso na carreira de $2^{\circ}$ Tenente do Quadro de Oficiais de Saúde da Polícia Militar de Minas Gerais para a função de médico proctologista não é justificada pela natureza das atribuições do cargo, eis que não se realizará atividade tipicamente militar. Com efeito, tal exigência se configura como discriminatória e destoante dos princípios da igualdade, da razoabilidade e da proporcionalidade:

A sentença, objeto do presente reexame, deve ser confirmada. É cediço que a Administração Pública tem a prerrogativa de estabelecer critérios para o ingresso de servidores em seus quadros, considerando as peculiaridades da profissão. Não obstante, tais requisitos devem ser objetivos, racionalmente justificáveis, respeitando os limites legais, para que não se traduzam em qualquer forma de discriminação. A meu inteligir, a exigência prevista na cláusula 4.1.4 do Edital do concurso para provimento de cargo de $2^{\circ}$ Tenente do Quadro de Oficiais de Saúde 
da Polícia Militar de Minas Gerais, qual seja, ter menos de 35 (trinta e cinco) anos de idade até a data da nomeação (fl. 24), exorbita aos princípios constitucionais da igualdade, da razoabilidade e da proporcionalidade. Com efeito, não há justificativa para impedir que Gustavo Ambrosi Evangelista participe do certame, devendo-lhe ser, outrossim, assegurado o direito à nomeação e posse (ocorrida aos 10 de abril de 2007), uma vez que, como noticiado na peça de fl. 163 , foi aprovado em $2^{\circ}$ lugar em sua categoria (Médico Proctologista). Não se pode descuidar de que a natureza do serviço a ser prestado pelo impetrante não guarda relação direta com força física, tampouco com a idade, ressalvando que o mesmo nasceu em 26/06/1968 (fl. 15), enquanto a previsão editalícia estipulou como data limite de nascimento 28/12/1971. A restrição representada pelo limite máximo de idade, diante das funções inerentes à atividade de médico, revela flagrante discriminação entre os candidatos, preterindo, injustificadamente, aqueles que, possuindo maior idade, ainda têm plenas condições de desempenhar perfeitamente as funções do cargo (MINAS GERAIS, TJMG, 2008).

Pelo exposto, pode-se perceber que o acórdão do Tribunal de Justiça de Minas Geria valese de fundamentos similares aos do acórdão do Supremo Tribunal Federal, mas chega-se à conclusão diferente. No entanto, não há disparidade decisória entre eles. É que as particularidades do caso tratado na decisão do referido tribunal estadual conduziram a uma solução aparentemente contrária àquela expressa na decisão do Supremo Tribunal Federal. Recorda-se que esta concluiu no sentido de que a exigência de idade limite de 35 anos para inscrição em concurso público para admissão em Curso de Formação de agente penitenciário, cargo que exige a prática de atividade tipicamente militar, é justificável e razoável. Já a decisão do tribunal estadual de Minas Gerais expressou entendimento no sentido de ser injustificável e configurativa de ato discriminatório a exigência de idade máxima de 35 anos para o ingresso na carreira de médico proctologista da Polícia Militar, porquanto as atividades de tal função não se relacionam com aquelas tipicamente militares. Vê-se que ambas as decisões são consentâneos à Constituição, a pesar de aparentemente contraditória.

Com isso, pretendeu-se acentuar que é indispensável a consideração das particularidades no caso concreto para se chegar à solução constitucionalmente adequada da demanda judicial. Não menos importante é a reconstrução dos fundamentos teórico-normativos de decisões pretéritas, havidas como precedentes, com a finalidade de que os sujeitos processuais possam posicionar-se criticamente em relação àqueles.

Não é por intermédio de mecanismo de vinculação de atos decisórios do Supremo Tribunal Federal que se atingiria à almejada certeza e segurança jurídica na aplicação do Direito. Tal desiderato, quando buscado no eixo do Estado Democrático de Direito, significa garantir aos cidadãos que suas pretensões jurídicas (lesão ou ameaça de lesão a direitos) serão 
apreciadas, e o Judiciário deve dar-lhes uma resposta adequada à constitucionalidade brasileira, expressa em decisão construída a partir (nunca apesar!) daquilo que as partes produziram em procedimento em contraditório, bem como seja consistente com o ordenamento jurídico (BAHIA, 2009, p. 220-221). Isso, por outro lado, exige também a assunção argumentativa da perspectiva do participante. Ou seja, daquele que num sistema jurídico não se limite a descrever quais foram as decisões tomadas, mas perquiri sobre a correção (validade) delas e, com isso, procura entender a natureza da argumentação jurídica desenvolvidas nas decisões (DWORKIN, 2007, p. 15-19) ${ }^{16}$. Nesse quadro de ideias, é imprescindível que os sujeitos processuais analisem criticamente as decisões pretéritas, invocadas como precedentes judiciais, visando à apreensão de seus correspondentes fundamentos teórico-normativos e não apenas à síntese de suas partes dispositivas ou ementas.

Daí a relevância atribuída à fundamentação das decisões vinculantes, porque é a partir dela que se aferirá a legitimidade de aplicação do Direito. É também pela reflexão crítica dos fundamentos decisórios que se permitirá modifica, ampliar, restringir e superar seus resultados.

Por conseguinte, o ponto nevrálgico das decisões vinculantes é a sua fundamentação jurídico-constitucional, e não a sua síntese conclusiva, embora esta ganhe a pretensão legal de vinculação. Salienta-se que é a partir de seus conteúdos que se infere qual é a ratio decidenti e o obter dictum. Vale dizer, grosso modo, qual a norma encaminhadora da decisão pretérita e quais são as razões periféricas àquela. Por último, é oportuno lembrar que em países de civil law

\footnotetext{
${ }^{16}$ Importa transcrever a explicação de Robert Alexy sobre a diferença entre a perspectiva do participante (ponto de vista interno) e a do observador (ponto de vista externo): "a perspectiva do participante é adotada por quem, num sistema jurídico, participa de uma argumentação sobre o que nele é ordenado, proibido, permitido e autorizado. No centro da perspectiva do participante está o juiz. Quando os outros participantes, tais como juristas, advogados ou cidadãos interessados no sistema jurídico apresentam argumentos a favor ou contra determinados conteúdos do sistema jurídico, eles se referem, em última instância, a como um juiz deveria decidir se pretendesse decidir corretamente. A perspectiva do observador é adotada por aquele que não pergunta o que é a decisão correta num determinado sistema jurídico, e sim como de fato se decide em determinado sistema. Exemplo de um observador desse tipo é o do americano branco de Norbert Hoerster, que, sob à vigência da leis do apartheid, queria viajar pela África do Sul com sua mulher de pele negra e se preocupava com detalhes jurídicos de sua viagem" (ALEXY, 2011, p. 30) (destaque do original). Interessante também são as considerações de Thomas da Rosa Bustamante acerca do tema: "No momento em que se abandona a perspectiva externa do Positivismo (que tenta construir uma teoria do Direito da perspectiva do observador, preocupada apenas em descrever o sistema jurídico tal como ele é) e se passa a assumir uma perspectiva interna que visa a estudar o Direito do ponto de vista dos próprios participantes do processo de produção de normas e decisões legítimas, percebe-se com clareza que a justificação do Direito como prática social e a justificação das decisões particulares tomadas com base no Direito não podem prescindir de uma metodologia, um processo racional para conciliar essa tensão entre a ratio e auctoritas, haja vista que o problema fundamental enfrentado pelos juízes na sua atividade de prática é justamente como construir uma solução bem ordenada do ponto de vista moral e, ao mesmo tempo, juridicamente válida" (BUSTAMANTE, 2012, p. 118-119) (destaque do original)
} 
ISSN 1981-3694

(DOI): $10.5902 / 1981369419761$

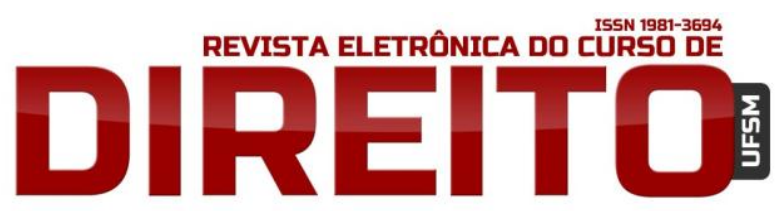

AS DECISÕES JUDICAIS NO CONTROLE DE CONSTITUCIONALIDADE E A SUA EFICÁCIA VINCULANTE NO ESTADO DEMOCRÁTICO DE DIREITO

não se aplica um decisão vinculante apenas pelo fato de ser resultado de entendimento de um tribunal ao contrário, a sua aplicação depende de saber quais as razões teórico-normativoconstitucionais foram enunciadas pela decisão. Daí a fundamentação do ato jurídico-processual da decisão judicial passa a ser sua parte mais importante, a despeito de sua parte dispositiva ser atingida pela coisa julgada, até porque se houver contraste entre o dispositivo e a fundamentação, a decisão é suscetível de nulidade.

\section{CONCLUSÃO}

Ante todo o exposto, ao se fazer uma leitura reflexiva da pretensão de atribuição de eficácia vinculante às decisões do controle de constitucionalidade, é possível, agora, sintetizar algumas incipientes conclusões.

Por primeiro, ao se analisar as decisões do controle de constitucionalidade (interpretação conforme à Constituição, declaração de nulidade parcial sem redução de texto, aditivas e substitutivas) deve-se, antes de tudo, perquirir a respeito de quais são os seus fundamentos teórico-normativos. Quer-se, com isso, afastar a acepção de que o judiciário exerce função criativa de direitos, que vem, aliás, ganhando força do discurso jurídico, principalmente pela atribuição de efeitos vinculantes a tais decisões, até porque elas se colocam no entremeio das funções legislativas e jurisdicional.

Nessa linha de reflexão, a partir da reconstrução crítica da fundamentação das decisões vinculantes é que se propõe que a aplicação dessas se impõe pelas suas razões justificantes (argumentos teórico-normativos), não pela vinculação legal. Assim, percebe-se que a simples menção da síntese da parte dispositiva ou da ementa da decisão vinculante é insuficiente para os propósitos de aplicação legítima do Direito na perspectiva do participante.

Além do mais, ao se abordar os objetivos da implementação de mecanismo de vinculação decisória, a saber: alcançar certeza e segurança jurídica por meio de uniformização de decisões e centralização do controle de constitucionalidade, pode-se apontar a sua inadequação constitucional. Primeiramente, pelo fato de que se os meios adotados serem destoantes dos preceitos democráticos da Constituição vigorante. Ademais, pelo fato de que "os problemas" da interpretação jurídica não se resolveram com o proferimento de decisões, mesmo que correta do ponto de constitucional e tomada pela mais alta corte do sistema brasileiro. 
ISSN 1981-3694

(DOI): $10.5902 / 1981369419761$

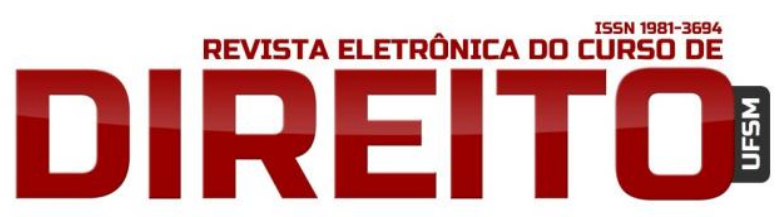

AS DECISÕES JUDICAIS NO CONTROLE DE CONSTITUCIONALIDADE E A SUA EFICÁCIA VINCULANTE NO ESTADO DEMOCRÁTICO DE DIREITO

Apontou-se pela imprescindibilidade, para se chegar à interpretação constitucionalmente adequada, das particularidades do caso concreto, porque os enunciados sintéticos e abstratos das decisões judiciais não conseguem (e não conseguirão) antever todas as suas hipóteses de desrespeito à Constituição. Inclusive, abordou-se tal questão com apoio num estudo comparativo entre dois acórdãos, um do Supremo Tribunal Federal, outro do Tribunal de Justiça de Minas Gerais. Essas decisões, com base em fundamentos similares, tiveram conclusões díspares. Porém, constitucionalmente adequadas, em vistas das peculiaridades fáticas de cada uma delas.

Essa leitura hermenêutica também viabilizou compreender que a certeza e segurança jurídica estão ligadas à legitimidade das decisões judiciais, na medida em que asseguram que o Judiciário não se esquive de apreciação das pretensões jurídicas (lesão ou ameaça de lesão) dos cidadãos, dando-lhes uma solução correta do ponto de vista constitucional e construída em contraditório pelas partes.

\section{REFERÊNCIAS}

ALEXY, Robert. Conceito e validade do direito. $1^{\mathrm{a}}$ ed. $2^{\mathrm{a}}$ tiragem. São Paulo: Martins Fontes. 2011: Tradução Gercélia Batista de Oliveira Nunes.

BAHIA, Alexandre Gustavo Melo Franco. Ingeborg Maus e o Judiciário como Superego da Sociedade. Revista CEJ (Brasília), Brasília, v. 30, p. 10-12, 2005.

- Constituição e processo: a decisão em sede de controle de constitucionalidade vista a partir da constitucionalização do processo. Revista Brasileira de Direito Constitucional, São Paulo, v.1, n.7, p. 102-133, jan. 2006.

Recursos extraordinários no STF e

STJ: conflito entre interesses público e privado. Curitiba: Júrua. 2009.

BARACHO JUNIOR, José Alfredo de Oliveira. Dimensões paradoxais da jurisdição constitucional. In: MACHADO, Felipe Daniel Amorim; CATTONI DE OLIVEIRA, Marcelo Andrade. (Org.) Constituição e processo: a contribuição do processo no constitucionalismo democrático brasileiro. Belo Horizonte: Del Rey, 2009, p. 153-167.

BARROS, Flaviane de Magalhães; MACHADO, Felipe Daniel Amorim. Prisões e medidas cautelares. Belo Horizonte: Del Rey. 2011.

BRASIL. Supremo Tribunal Federal. Recurso Extraordinário176479-1/RS. Relator ministro Moreira Alves. Primeira Turma. Diário de Justiça, Brasília, 05 set. 1997. 
ISSN 1981-3694

(DOI): $10.5902 / 1981369419761$

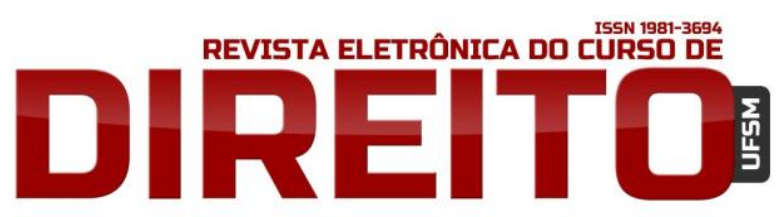

AS DECISÕES JUDICAIS NO CONTROLE DE CONSTITUCIONALIDADE E A SUA EFICÁCIA VINCULANTE NO ESTADO DEMOCRÁTICO DE DIREITO

. Supremo Tribunal Federal. Habeas Corpus 79812/SP. Relator Celso de Mello, Tribunal Pleno. Diário de Justiça, Brasília, 16 fev. 2001.

. Supremo Tribunal Federal. Ação Direta de Inconstitucionalidade $n^{\circ} 3324-7 / D F$. Relator ministro Marco Aurélio, Tribunal Pleno. Diário de Justiça, Brasília, 06 ago. 2005 (a).

. Superior Tribunal de Justiça. Recurso Especial No 121639/ RS. Relator ministro Adilson Vieira Macabau (desembargador convoca do Tribunal de Justiça do Rio de Janeiro), Quinta Turma. Diário de Justiça. Brasília, 17 out. 2011.

Supremo Tribunal Federal. Habeas Copus 110844/RS. Relator ministro Ayres Brito, Segunda Turma. Diário de Justiça, Brasília, 19 jun. 2012 (a).

.. Supremo Tribunal Federal. Habeas Corpus 104339/SP. Relator ministro Gilmar Mendes, Tribunal Pleno. Diário de Justiça, Brasília, 10 mai. 2012 (b).

BUSTAMANTE, Thomas da Rosa. Teoria do precedente judicial: a justificação e aplicação de regras jurisprudências. São Paulo: Noeses. 2012.

CATTONI DE OLIVEIRA, Marcelo de Andrade. Direito processual constitucional. Belo Horizonte: Mandamentos. 2001.

- Interpretação como ato de conhecimento e como ato de vontade: a tese kelseniana da interpretação autêntica. In: CATTONI DE OLIVEIRA, Marcelo Andrade. (org.) Jurisdição e hermenêutica no Estado Democrático de Direito. Belo Horizonte: Mandamentos, 2004, p. 121-150.

Devido processo legislativo: uma justificação democrática do controle jurisdicional de constitucionalidade das leis e do processo legislativo. $2^{\mathrm{a}}$ ed. Belo Horizonte: Mandamentos, 2006.

COPETTI NETO, Alfredo; MACHADO, Felipe. Daniel. Amorim. A hermenêutica jurídica em defesa da civilização: uma contraposição à barbárie teleológica dos tribunais. In: CATTONI DE OLIVEIRA, Marcelo Andrade; MACHADO, Felipe. Daniel Amorim (Org.) Constituição e Processo: a

contribuição do Processo ao Constitucionalismo Democrático brasileiro. Belo Horizonte: Del Rey, 2009, p. 183-196.

CORDEIRO LEAL, André. Direito Processual - texto jurídico e norma processual: implicações hermenêuticas. In: Rosemiro Pereira Leal. (Org.). Estudos Continuados de Teoria do Processo. Porto Alegre: Síntese, 2000, p. 115-121.

DWORKIN, Ronald. 0 império do direito. $2^{\mathrm{a}}$ ed. São Paulo: Martins Fontes. 2007: Tradução Jefferson Luiz Camargo.

GRAU, Eros Roberto. Sobre a produção legislativa e sobre a produção normativa do direito oficial: o chamado "efeito vinculante". Revista Trimestral de Direito Público, São Paulo, n. 16, p. 31-38, 1996.

HABERMAS, Jürgen. Direito e democracia: entre facticidade e validade. Rio de Janeiro: Tempo 
Brasileiro, 1997. Volume I. Tradução: Flávio Beno Siebeneichler.

HÄBERLE, Peter. Hermenêutica constitucional: a sociedade aberta dos intérpretes da constituição: contribuição para a interpretação pluralista e 'procedimental' da constituição. Porto Alegre: S. A. Fabris, 1997. Tradução: Gilmar Ferreira Mendes.

KELSEN, Hans. Teoria pura do direito. 6. ed. $5^{a}$ tiragem São Paulo: Martins Fontes, 2003. Tradução: João Baptista Machado.

LEAL, Rosemiro Pereira. Teoria geral do processo: primeiros estudos. $8^{\mathrm{a}}$. Ed. Belo Horizonte: Forense, 2009.

MAUS, Ingeborg. Judiciário como superego da sociedade: o papel da atividade jurisprudencial na sociedade órfã. Novos Estudos CEBRAP, São Paulo, n. 58, p. 185, nov. 2000.

MEYER, Emílio Peluso Neder. A decisão no controle de constitucionalidade. São Paulo: Método, 2008

MENDES, Gilmar Ferreira. Jurisdição constitucional: o controle abstrato de normas no Brasil e na Alemanha. 5. ed. São Paulo: Saraiva, 2005.

. Limitação dos efeitos no sistema difuso e a aplicação do art. 27 da Lei 9.868/99: algumas notas. In: MACHADO, Felipe Daniel Amorim; CATTONI DE OLIVEIRA, Marcelo Andrade. (Org.) Constituição e processo: a contribuição do processo no constitucionalismo democrático brasileiro Belo Horizonte: Del Rey, 2009, p. 29-38.

MINAS GERAIS. Tribunal de Justiça de Minas Gerais. Apelação 1002406989651-2/002. Relator desembargador Armando Freire. $1^{\text {a }}$ Câmara Cível. Diário de Justiça, Minas Gerais. 04 mar. 2008.

NUNES, Dierle José Coelho. Processo jurisdicional democrático: uma análise crítica das reformas processuais. Curitiba: Juruá, 2009.

PENNA, Saulo Versiani. A decisão de efeito vinculante na teoria do processo jurídico contemporâneo: sua legitimidade sob o paradigma do Estado democrático de direito. 2004. 153f. Dissertação (Mestrado) - Pontifícia Universidade Católica de Minas Gerais, Programa de Pós-Graduação em Direito.

RIO GRANDE DO SUL. Tribunal de Justiça. Habeas Corpus 70030667489. Relator Desembargador Marcel Esquível Hoppe, Primeira Câmara Criminal. Diário de Justiça, Porto Alegre, 19 de ago. 2009.

SAMPAIO, José Adércio Leite. As sentenças intermediárias de constitucionalidade e o mito do legislador negativo. In: SAMPAIO, José Adércio Leite; SOUZA CRUZ, Álvaro Ricardo de. (Org.) Hermenêutica e Jurisdição Constitucional. Belo Horizonte: Del Rey, 2001, p. 159-194.

SANTA CATARINA. Juízo de Direito da Vara da Infância de Juventude - Comarca de Joinville/SC. Ação Civil Pública autos nº 03803008229-0. Diário de Justiça, Joinville, 12 de mai. 2003.

SILVA FILHO, Alberico Alves. Jurisdição constitucional e judicação na teoria do Direito 
ISSN 1981-3694

(DOI): $10.5902 / 1981369419761$

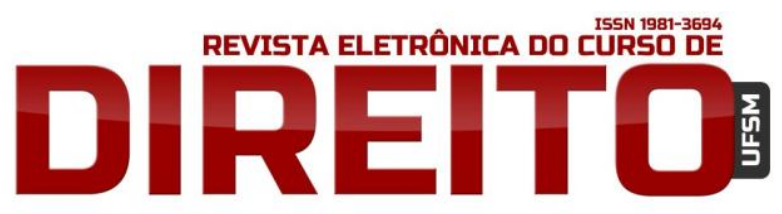

AS DECISÕES JUDICAIS NO CONTROLE DE CONSTITUCIONALIDADE

E A SUA EFICÁCIA VINCULANTE NO ESTADO DEMOCRÁTICO DE DIREITO

GUILHERME CÉSAR PINHEIRO RICARDO NOBREGA

democrático. In: Rosemiro Pereira Leal. (Org.). Estudos continuados de teoria do processo. Porto Alegre: SÍNTESE, 2003, v. III, p. 127-179.

SOUZA CRUZ, Álvaro Ricardo. Jurisdição constitucional democrática. Belo Horizonte: Del Rey, 2004.

. Habermas e o direito brasileiro. $2^{\text {a }}$ ed. Rio de Janeiro: Lumen Juris, 2006.

TARUFFO, Michele. Aspetti fondamentali del processo civile di civil law e di common law.

Revista da Faculdade de Direito da Universidade Federal do Paraná, Curitiba, v.36, p.27-48, jul. 2001(a).

. Legalità e giustificazione della creazione giudiziaria del diritto. Rivista

trimestrale di diritto e procedura civile, v. 55, n. 1, p. 11-31, mar. 2001 (b).

THEODORO JÚNIOR, Humberto; NUNES, Dierle José Coelho; BAHIA, Alexandre. Breves considerações sobre a politização do judiciário e sobre o panorama de aplicação do direito brasileiro: análise da convergência entre o civil law e o common law e dos problemas da padronização decisória. Revista de Processo, São Paulo, Ano 35, n. 189, p. 09-52, nov. 2010.

WEBER, Max. Três tipos puros de dominação legítima. In: WEBER, Max. Sociologia. 7. ed. São Paulo: Ática, 2004. p. 128-141.

Recebido em: 01/10/2015 / Revisões requeridas em: 26/11/2015 / Aprovado em: 07/12/2015 